\title{
The Genetic Basis of Addictive Disorders
}

\author{
Francesca Ducci, MD, PhDa and David Goldman, MD ${ }^{\mathrm{b},{ }^{*}}$ \\ anstitute of Psychiatry, Psychological Medicine, Kings College, Box P063, De Crespigny Park, \\ London SE5 8AF, UK
}

bLaboratory of Neurogenetics, National Institute on Alcohol Abuse and Alcoholism, National Institutes of Health, 5625 Fishers Lane, Rockville, MD 20852, USA

\section{Keywords}

Substance use disorder; Heritability; MAOA; COMT; HTR2B

\begin{abstract}
Addictions, including substance use disorders (SUDs), are multistep conditions that, by definition, require exposure to an addictive agent. The wide variety of addictive agents encompasses drugs, foods, sex, video-gaming, and gambling. Any of these agents may lead to an "addicted state" through neurobiologic pathways partially overlapping with those involved in addiction to psychoactive substances. ${ }^{1}$ Millions of people are exposed to addictive agents each year, for instance, in the course of medical care for treatment of pain. The vast majority do not become addicted, even if temporary tolerance and dependence are elicited. The probability of initial use and the probability of progression toward a pathologic pattern of use are influenced by intrinsic factors (eg, genotype, sex, age, age at first use, preexisting addictive disorder, or other mental illness), extrinsic factors (eg, drug availability, peer influences social support, childhood adversity, parenting style, socioeconomic status), and the nature of the addictive agent (eg, psychoactive properties, pharmacokinetics, mode of use or administration). The relative importance of these factors varies across the lifespan and at different stages of addiction. For example, peer influences and family environment are most important for exposure and initial pattern of use, whereas genetic factors and psychopathology play a more salient role in the transition to problematic use. $^{2}$
\end{abstract}

In individuals who are vulnerable to addiction, repetitive exposure to the agent induces longlasting neuroadaptative changes that further promote drug-seeking behaviors and ultimately lead to persistent and uncontrolled patterns of use that constitute addiction. These neuroadaptive changes are the bases for tolerance, craving, and withdrawal and lead to a motivational shift. ${ }^{3}$ Motivation to drug-seeking behavior is initially driven by impulsivity and positive reward. In contrast, compulsivity and negative affect dominate the terminal stages of the pathology. Addictions are in a sense "end-stage" diagnoses because at the time diagnosis is made potentially irreversible neuroadaptative change have occurred-changes that were preventable at an early point of the trajectory of the illness.

The use and abuse of legal and illegal psychoactive substances is a worldwide public health priority with repercussions on the individuals, their families, and society. According to the World Health Organization (WHO), alcohol subtracts 69.4 million of disability-adjusted life 
years (DALYs) ${ }^{4}$; tobacco, 59.1 million; and illicit drugs, 12.2 million. ${ }^{5}$ From an economic perspective, the cost of substance use and SUDs in the United States is approximately $\$ 484$ billion/year, which is comparable to the cost of diabetes ( $\$ 131.7$ billion/year) and cancer (\$171.6 billion/year). ${ }^{6}$

\section{Heritability of Addictions}

Evidence from family, adoption, and twin studies converges on the relevance of genetic factors in the development of addictions including SUDs and gambling. ${ }^{7-13}$ Weighted mean heritabilities for addictions computed from several studies of large cohorts of twins are shown in Fig. $1 .{ }^{14}$ Heritability is lowest for hallucinogens $(0.39)$ and highest for cocaine (0.72).

Heritability estimates are usually higher for addiction than for substance use; however, "no pathologic drug use" and "initiation of use" are also heritable, indicating that genetic influences play a role also in initiation. ${ }^{10,12,15}$

\section{Mode of Inheritance}

The identification of specific genes and functional loci moderating vulnerability has been challenging because of the genetic complexity of addictive disorders. This complexity derives from multiple sources including incomplete penetrance, phenocopies, variable expressivity, gene-environment interactions, genetic heterogeneity, polygenicity, and epistasis.

Twin studies can to some extent disentangle the roles of genetic heterogeneity and polygenicity-epistasis. As shown in Fig. $2,{ }^{14}$ under the epistatic model, combinations of genetic variants, each represented as a puzzle piece, determine phenotypes.

In contrast, under the genetic heterogeneity model, different genetic variants lead to the same phenotype in different individuals, but a single genetic variant can suffice. In twin studies epistasis leads to high monozygotic/dizygotic (MZ/DZ) concordance ratios, as shown in Fig. 3.

Because MZ twins share all alleles and DZ twins only on average half, epistatic models predict higher MZ/DZ concordance ratios. If a multigene combination is required, the MZ/ $\mathrm{DZ}$ ratio is higher, and it is very high if a multilocus epistatic combination is required. The odds that DZ twins will inherit a combination of alleles is 0.5 raised to the power of the number of alleles involved in the combination, $(0.5)^{n}$. Multiple combinations may lead to the same phenotype, but for multilocus interactions this is less likely to compensate for the problem of joint probability to produce exactly 2:1 and 4:1 MZ/DZ ratios, as are expected for single alleles acting dominantly or recessively acting on a dichotomous trait, or for multiple alleles additively contributing to a quantitative trait. The MZ/DZ ratio for autism appears to be as high as 50:1, indicating that epistasis is likely. However, the MZ/DZ twin concordance ratios for SUDs (Fig. 4) converge on 2:1, consistent with alleles of individual effect and with the genetic heterogeneity model.

Gene $\times$ gene interaction in addiction has been evaluated using identified loci. However, the paucity of such loci identified so far would be insufficient for generalizations. Perhaps only by chance, the few gene $\times$ gene interaction studies performed so far in addiction are consistent with the genetic heterogeneity model and gene-gene additivity. In alcoholism, the protective effects of missense variants in ADH1B (Arg48) and ALDH2 (Lys487) are additive, ${ }^{16}$ which is perhaps not the expected result because these variants affect consecutive steps in the alcohol metabolic pathway and mediate propensity to alcohol-induced flushing. 
An additive effect on risk for alcoholism comorbid with other SUDs has been reported for functional loci mapping within the serotonin $3 \mathrm{~B}$ receptor $(H T R 3 B)$ and serotonin transporter (SLC6A4) genes. ${ }^{17,18}$ In nicotine addiction, two variants associated with smoking appear to act additively. ${ }^{19}$ These nicotine addiction risk variants map in the CHRNA5-CHRNA3CHRNB4 nicotinic acetylcholine receptor subunit cluster and in the TTC12-ANKK1$D R D 2$ cluster, which includes $D R D 2$, a dopamine receptor important in nicotine reward. In a community sample of 5000 Finns, the alleles most significantly associated with smoking were CHRNA5 Asp398Asn and an intronic variation within TTC12 (rs10502172).

Adolescent carriers of three to four risk alleles at these two loci (20\% of the population) had a threefold increase in odds of smoking regularly and 2.5 -fold increased odds of occasionally smoking as compared to noncarriers, who constitute $9 \%$ of the population. Carriers of one or two risk alleles were at intermediate risk. A similar stepwise increase in risk with allele dosage was observed in adulthood, and again consistent with additivity (Fig. $5)$.

The polygenic nature of addiction has implications for the manner in which genetic predictors may eventually be used in treatment and genetic counseling. The loci detected so far, including CHRNA5 Asp398Asn, which has a verified role in smoking, have little predictive value. However, as more genetic risk variants for addiction are discovered and personalized genotyping and sequencing become widespread, there will be increased efforts to use multilocus genetic risk scores to predict vulnerability. ${ }^{20}$

\section{Changes in Gene Effects Across the Lifespan}

Genetic and environmental influences modulating risk of SUDs change developmentally and across the lifespan. In a longitudinal twin study, Kendler and colleagues ${ }^{21}$ found that gene effects in alcohol, cannabis, and nicotine addictions were low in early adolescence but their relative importance gradually grew in adulthood. In contrast, the effect of family environment declined from childhood to adulthood. A possible explanation is that as they mature, people have increasing latitude to shape their choices and social environments, thus increasing the relative importance of genotype. ${ }^{22}$ Another explanation is that some genetic factors are important only after repetitive exposure to addictive agents. Also, some alleles may only alter responses of the adult brain. Genetic variation within the CHRNA5CHRNA3-CHRNB4 gene cluster appears to have a stronger effect on smoking behavior in adulthood than in adolescence and moderated the risk of developing a severe pattern of smoking in subjects who had already initiated nicotine use. ${ }^{19}$ In contrast, the TTC12$A N K K 1-D R D 2$ and $M A O A$ appears to influence personality characteristics such as novelty seeking and impulsivity that promote substance initiation. ${ }^{19}$

\section{Shared and Unshared Inheritance}

Several addictive disorders tend to co-occur in the same individual. ${ }^{23-25}$ Studies on genetically informative samples (eg, adoptive or twin studies) can measure the relative contribution of genes and environment to this comorbidity by evaluating the frequency of cross-transmission. ${ }^{26}$ Twin studies reveal an overlap between genetic influences for alcoholism and illicit drug use disorders ${ }^{27,28}$ and between alcoholism and smoking. ${ }^{29}$ Kendler and colleagues ${ }^{30}$ explored the effect of shared genetic influences on addiction to alcohol, caffeine, nicotine, cannabis, and cocaine in a portion of the Virginia twin sample including 5000 participants. In this study genetic risk could not be explained by one factor acting across all substances. Rather, two shared factors were found: an illicit agent factor mainly explaining vulnerability to cannabis and cocaine dependence and a licit agent factor mainly explaining vulnerability to alcohol, caffeine, and nicotine. 
SUDs are frequently comorbid with other mental illnesses including internalizing disorders, such as depression and anxiety, and externalizing disorders, such as conduct disorder (CD), antisocial personality disorder, borderline personality disorder, and attention-deficit/ hyperactivity disorder (ADHD). ${ }^{24,25,31}$ Twin studies indicate shared genetic influences between SUDs and externalizing disorders. ${ }^{27,28,32}$ Longitudinal studies have shown that CD and ADHD are important risk factors for addiction. ${ }^{33}$ In contrast, twin studies have failed to reveal a shared genetic vulnerability between addiction and internalizing disorder, and it has been suggested that anxiety and depression are more commonly a consequence rather than a risk factor for addiction, being related to neuroadaptation and with drawal. ${ }^{34,35}$ However, longitudinal studies have shown that some anxiety disorders and anxiety-related personality traits such as panic disorder, social phobia, and increased harm avoidance predict subsequent alcohol problems in adoles cents and young adults. ${ }^{36}$

Overall, twin studies predict that genes involved in vulnerability to SUDs include both substance-specific genes and genes that act on common pathways involved in addiction to different agents and propensity to other psychiatric disorders. Substance-specific genes include genes for metabolic enzymes $(A L D H 2, A D H 1 B)$ as well as genes encoding gatekeeper molecules such as drug receptors (eg, nicotinic receptors, OPRM1). On the other hand, genes influencing diverse aspects of addiction neurobiology including anxiety, impulsivity, and reward, including genes such as monoamine oxidase $\mathrm{A}(M A O A)$, the serotonin transporter (SLC6A4), and catechol-O-methyl transferase (COMT), have been implicated in the shared genetic liability between addictions and other psychiatric diseases.

\section{Interplay between Genetic and Enviromental Factors}

The gene (nature) versus environment (nurture) debate represented a misguided and polarizing, dichotomy. Genetic and environmental factors interact in complex ways ${ }^{37}$ but there are two main types of violations of gene-environment independence: gene $\times$ environment interaction and gene $\times$ environment correlation.

Gene $\times$ environment correlation ( $\mathbf{r G E}$ ) occurs when genotype correlates (r) with probability of exposure to an environmental factor. Twin studies can address the existence of rGE by measuring the "genetics of the environment." A gene-based example of rGE is the effect of CHRNA5 Asn398 to increase risk of lung cancer. ${ }^{38}$ This functional allele is associated with heavy smoking, thereby leading to increased exposure to carcinogens.

Gene $\mathbf{x}$ environment interaction $(\mathbf{G} \times \mathbf{E})$ occurs when the effect of the environmental exposure on an outcome is modified by genotype (for review see Ref. ${ }^{39}$ ). Stressors occurring early in life, such as childhood adversity, are well known risk factors for addiction and comorbid conditions, including antisocial personality disorder (ASPD), CD, borderline personality disorder, and anxiety disorders. However, not all people exposed to early trauma develop psychopathology, indicating differences in resiliency. Functional loci that contribute to interindividual differences in stress resiliency include monoamine oxidase $\mathrm{A}(M A O A),{ }^{40}$ the serotonin transporter $(S L C 6 A 4),{ }^{41} C O M T T^{42}$ the corticotrophin-releasing hormone receptor 1 gene, neuropeptide $\mathrm{Y},{ }^{43}$ FKBPS, ${ }^{44}$ the glucocorti coid receptor (GR) gene $(N R 3 C 1),{ }^{45}$ and the adenylate cyclase activating poly peptide 1 (pituitary) receptor type gene $(A D C Y A P 1 R 1) .{ }^{46}$

\section{Intermediate Phenotypes}

One strategy to discover gene effects in etiologically complex diseases such as addiction is the deconstruction of phenotypes into elements that are etiologically less complex.

Intermediate phenotypes access mediating mechanisms of genetic and environmental 
influences. Heritable intermediate phenotypes that are disease associated are termed endophenotypes. $^{47}$

Alcohol-induced flushing is a protective alcohol-related endophenotype influenced by alleles mediating variation in alcohol metabolism. Low response to alcohol is an endophenotype predictive of alcoholism risk. ${ }^{48-50}$ In humans, level of response is due mainly to pharmacodynamic variation in response ${ }^{51}$ rather than variation in metabolism. Low response to alcohol has been associated with genetic variation in the serotonin transporter gene (SLC6A4) and in the gene encoding the subunit a6 of the $\gamma$-aminobutyric acid receptor $\mathrm{A}(G A B R A 6) .{ }^{52}$ Other addiction-relevant intermediate phenotypes include electrophysiologic, neuropsychological, neuroendocrinologic, and, more recently, neuroimaging measures. Neuroimaging accesses neuronal mechanisms underlying emotion, reward, and craving and has thereby enabled linkage of genes to neuronal networks relevant in addiction (for review see Ref. ${ }^{53}$ ). For example, amygdala activation after exposure to emotional imagery and stressful stimuli captures interindividual differences in emotional response. ${ }^{54}$ As discussed in the text that follows, amygdala activation is influenced by $S L C 6 A 4$ and MAOA. On the other hand, task-elicited activation of the prefrontal cortex accesses prefrontal cognitive function that is impaired in several psychiatric diseases including addictions and has been linked to genetic variation within COMT and $M A O A$. Activation of the ventral striatum and other brain areas during positive reward allows exploration of reward circuits ${ }^{55}$ enabling the observation that the OPRM1 Asn398Asp variant associated with altered naltrexone treatment response also modulates reward processes in the ventral striatum. ${ }^{56}$ Effect sizes of genetic variants on intermediate phenotypes appear to be larger than effects on complex disease phenotypes, potentially reflecting proximity to gene action, measurement properties, and specificity. ${ }^{43,57}$

\section{Gene Identification}

Candidate gene and genome-wide analyses are increasingly integrated to identify genetic variations influencing addiction. In the former, genes known to influence the pathogenesis or treatment of addictions are selected, for example, based on discoveries in animal pharmacobehavioral and genetic studies or based on what is known about the pharmacokinetics and pharmacodynamics of the drug. In genome-wide studies, the genome is interrogated in a hypothesis-free way.

\section{Candidate Genes}

Alcohol-metabolizing genes: ADH1B and ALDH2-Polymorphisms in the genes encoding for the alcohol-metabolizing enzymes such as the alcohol dehydrogenase IB (ADH1B) and aldehyde dehydrogenase 2 (ALDH2) influence alcohol consumption and risk of alcohol use disorders. ADH1B and ALDH2 catalyze consecutive steps in alcohol metabolism. In adults, these enzymes play an important role although several other enzymes also catalyze these metabolic steps, including catalase, cytochrome $\mathrm{P} 450$, and other enzymes in the ADH and ALDH gene families. ADH oxidizes ethanol to acetaldehyde, which is then converted to acetate by ALDH. Acetaldehyde is toxic and adducts with both proteins and DNA. Both acetaldehyde and alcohol are recognized as mutagens. Acetaldehyde is a potent releaser of histamine, and thereby triggers flushing, an aversive reaction characterized by headache, nausea, palpitations, and flushing of the skin. Ordinarily, acetaldehyde is rapidly converted to acetate, and levels of acetaldehyde are very low even after alcohol ingestion. However, if aldehyde dehydrogenase is blocked by disulfiram (a medication used to help alcoholics maintain abstinence) then flushing is observed after ingestion of small quantities of alcohol. The acetaldehyde accumulation can lead to increased risk of upper gastrointestinal (GI) cancer, and cancer risk is greatly augmented by pharmacologic blockade of aldehyde dehydrogenase or natural genetic variation. ${ }^{58}$ As shown in Fig. 6 , 
there are two common enzyme variants of ADH1B and ALDH2 that lead to alcohol-induced flushing, that are protective against alcoholism, and that play a role in the risk of upper GI cancer associated with alcohol consumption (Fig. 7).

At the $A D H 1 B$ His $48 A \operatorname{Arg}$ locus (rs1229984), the His 48 allele directly leads to increased catalytic efficiency of $A D H 1 B$. Indeed, the rate of oxidation of ethanol to acetaldehyde is increased 100-fold in His48/His48 homozygotes compared to Arg48/Arg 48 homozygotes. At the ALDH2 Glu487Lys locus (rs671), the Lys487 allele dominantly inactivates ALDH2. Higher ADH1B activity or lower ALDH2 activity lead to accumulation of acetaldehyde and flushing following consumption of small quantities of alcohol. In East Asian populations in which both $H i s 48$ and $L y s 487$ are highly abundant, and in Jewish populations in which His 48 is abundant, many individuals carry genotypes protective against alcoholism. Recently, the protective effect of the His 48 ADH1B variant on alcohol dependence was also demonstrated in European and African populations. ${ }^{59}$ Following up the connection of acetaldehyde to mutation, both the $A D H 1 B$ and $A L D H 2$ flushing alleles have been associated with enhanced risk of cancers of the oropharynx and esophagus. ${ }^{58}$ As seen in Fig. 7, rates of upper GI cancer are higher in parts of the world where the ALDH2 Lys 487 allele is abundant.

The $A D H 1 B$ and $A L D H 2$ polymorphisms are ancient, occurring on characteristic and highly diverged haplotypes. It is unlikely that either generic variant was selected to high frequency to reduce the likelihood of alcoholism after the introduction of alcohol into these populations, which probably occurred well after the spread of the polymorphisms. It has been hypothesized that $\mathrm{Arg} 48$ and/or Lys 487 were selected to high frequencies in East Asian populations because they alter susceptibility to protozoal infections of the gut, including amebiasis. ${ }^{60}$ These infections are sometimes treated with metronidazole, which potently inhibits aldehyde dehydrogenase. ${ }^{60}$

\section{Genes-Moderating Monoamines}

Monoamines including serotonin (5-hydroxytryptamine, 5-HT), norepinephrine (NE), and dopamine (DA) are modulators of emotionality, cognition, and reward. Therefore, it is unsurprising that genes regulating monoamines such as catechol- $O$-methylrans-ferase (COMT) and the serotonin transporter (SLC6A4) have been implicated in vulnerability to several psychiatric diseases, including addictions.

COMT metabolizes dopamine and norepinephrine and others catechols. COMT plays an important role in the regulation of dopamine in the prefrontal cortex, where the dopamine transporter is less expressed. ${ }^{61,62}$ COMT knockout mice have increased levels of dopamine in this brain region. ${ }^{63,64}$ The $C O M T$ gene has two promoters that control the transcription of two different mRNAs and encode a soluble, cytoplasmic protein (S-COMT) and a membrane-bound form (MB-COMT) which-in humans-has 50 additional amino acid residues at the $\mathrm{N}$-terminus. S-COMT predominates in most tissues, accounting for $95 \%$ of total COMT activity. ${ }^{65}$ In brain, where MB-COMT activity is much higher, ${ }^{66}$ this enzyme is located in the cell body, axons, and dendrites of cortical neurons. ${ }^{67}$ Val158Met is a common functional single nucleotide substitution of COMT, ${ }^{68}$ replacing methionine for valine at codon 158 of MB-COMT and at codon 108 of S-COMT. Via its effect on enzyme stability 69,70 the Met 158 allele is three- to fourfold less active. ${ }^{71}$ Because of its higher activity, the Val158 allele was predicted to lower dopamine level in the frontal cortex. Congruent with this hypothesis, the Val158 allele has been associated with inefficient frontal lobe function evaluated with different psychological and neuroimaging methodologies. ${ }^{72-74}$ Also, in a pharmacogenetic study, the COMT inhibitor tolcapone improved executive function in vall val homozygotes, but not in individuals homozygous for the met allele, indicating that this drug might correct the higher COMT activity, and consequent lower 
dopamine level, of $\mathrm{Val}$ carriers. ${ }^{75}$ On the other hand, Met158, although associated with better cognitive performance, is associated with decreased stress resilience and increased anxiety. This allele has been associated with increased anxiety in women, ${ }^{76}$ which might be explained because $C O M T$ promoters are down-regulated by estrogens. ${ }^{77}$ The Met allele has also been associated with increased pain-stress response and a lower pain threshold, ${ }^{42,78}$ and with increased amygdala reactivity to unpleasant stimuli. ${ }^{79}$ Results from studies exploring the association between COMT and addiction are mixed. Some studies failed to find evidence for an associations ${ }^{80}$; some indicate $\operatorname{Val158}$ as the risk alleles and others indicate the Met158 alleles as the risk allele. The Val158 allele was found to be in excess among methamphetamine, nicotine, and polysubstance addicts. ${ }^{80-82}$ On the other hand, in addicted populations with high frequencies of internalizing disorders, such as late-onset alcoholics in Finland ${ }^{83}$ and Finnish social drinkers, ${ }^{84}$ increased risk appeared to be conferred by the Met 158 allele.

\section{SLC6A4}

The serotonin transporter (SLC6A4) regulates synaptic levels of serotonin, a neurotransmitter involved in the regulation of mood, appetite, and impulse control. Reflecting these diverse actions, serotonin-specific reuptake inhibitors are the most commonly prescribed category of medications for mental illness. The serotonin transporter gene $S L C 6 A 4$ has a common variable number tandem repeat (VNTR) in its promoter region (HTTLPR) (Fig. 8) that is the most frequently studied locus in psychiatric genetics.

The major alleles within this VNTR differ in the number of copies of a 20- to 23-bp imperfect repeated sequence. The $L$ allele, which leads to increased transcriptional efficiency, has 16 copies of the repeat and the $S$ allele has 14 copies. ${ }^{85}$ Further, there is a relatively common, functional A $>$ G single-nucleotide polymorphism (SNP) within the $L$ allele, ${ }^{86}$ the $L_{G}$ allele being equivalent to the $S$ allele in transcriptional efficiency ${ }^{86}$ Further supporting the functional effect of HTTLPR, this locus has been shown to regulate serotonin transporter expression in postmortem brain ${ }^{87}$ and in vivo using single-photon emission computed tomography (SPECT) imaging ${ }^{88}$ although not in all studies. ${ }^{89}$ Low-transcribing $H T T L P R$ genotypes have been inconsistently associated with anxiety, depression, and alcoholism. However, the effects of this locus on complex behavior appear stronger if environmental exposure is also considered. HTTLPR moderated the impact of stressful life events on risk of depression and suicidal behavior ${ }^{90}$ Carriers of the low-transcribing $S$ allele exhibited more depression and suicidality after stressful life events than $L$ individuals with two copies of the allele. ${ }^{90}$ Although a meta-analysis failed to support this $\mathrm{G} \times \mathrm{E}$ interaction, ${ }^{91}$ other metanalyses have, and multiple lines of evidence support a role for $H T T L P R$ regulation of emotion and response to stress. In particular, HTTLPR has been shown to influence the activity of the amygdala, a brain region that regulates emotional response to environmental changes and that is involved in the pathogenesis of depression and anxiety. Both adults ${ }^{41}$ and children ${ }^{92}$ carrying the low-activity s allele displayed increased amygdala reactivity to fearful stimuli, reduced amygdala volume, ${ }^{93}$ and enhanced functional coupling between the amygdala and the ventro medial prefrontal cortex,${ }^{94} \mathrm{a}$ brain region that ordinarily represses amygdala activation. In addition, HTTLPR appears to predict stress-induced cortisolrelease. ${ }^{95} H T T$ gene $\times$ environment interactions have also been observed in animal models. The rhesus macaque has an orthologous polymorphism (rh-5HTTLPR) in the promoter region of serotonin transporter gene. In these animals, early life stress exposure led to dyscontrolled behavior and enhanced stress response later in life (for review see Ref. ${ }^{96}$ ). Consistent with findings in humans, rh-5HTTLPR influenced alcohol consumption and stress response, depending on rearing conditions. Carriers of the low-expression serotonin transporter genotype that were separated from their moth ers at an early age displayed higher stress reactivity and ethanol preference. ${ }^{97}$ Similarly to humans, ${ }^{95}$ 
the combined effect of $r h-H T T L P R$ and environment on stress reactivity appeared to be mediated by the hypothalamic-pituitary-adrenal (HPA) axis.

\section{Genome-Wide Association Studies}

As compared to candidate gene studies, genome-wide association studies (GWAS) have the advantage of covering the entire genome in an hypothesis-free way, and the methodology is powerful for detecting relatively common alleles (minor allele frequency $[\mathrm{MAF}]>5 \%$ ) of moderate effect. As discussed later, the impact of less common variants cannot be studied by using the current GWAS arrays and requires sequencing strategies. Another advantage of GWAS is that the same genotyping arrays are obtained in different samples facilitating the combination of results from different studies in meta-analyses. This is a crucial aspect because extremely large study samples are necessary to be able to detect the small effects of many common variant on complex diseases. Of note in GWAS, up to 5 million SNPs can be simultaneously tested raising the issue of false positives due to multiple testing. To achieve an effective $P$ value of .05, the genome-wide significance threshold is usually set at approximately $10^{-8}$.

GWAS for addictions is at a relatively early stage. Several addictions have yet to be evaluated by GWAS and the samples that have been studied thus far have either not been very large $(<10,000)$, or have been flawed by cross-site or cross-country heterogeneity, less than optimal phenotyping, and an insufficient number of subjects with extreme phenotypes. So far, the strongest, and confirmed, locus detected by GWAS is for the CHRNA5CHRNA3-CHRNB4 gene cluster on chromosome 15q25. ${ }^{38,98-102}$ This region harbors a locus-altering propensity to nicotine addiction. Nicotinic acetylcholine receptors (nAChRs) are pentameric cholinergic receptors that form ligand-gated ion channels. They are key mediators of the effect of nicotine on the central nervous system. Neuronal subtypes of nAChRs include various homomeric or heteromeric combinations of 12 different nicotinic subunits: $\alpha 2$ through a 10 and $\beta 2$ through $\beta 4$. The CHRNA5-CHRNA3-CHRNB4 gene cluster encodes for the $a 5, \alpha 3$, and $\beta 4$ subunits. Association of genetic variation within this region to smoking behavior was initially discovered using a candidate gene approach ${ }^{99,100}$ but was subsequently replicated by GWAS. GWAS detect a highly significant peak on chromosome 15q25 corresponding to the region where these three genes are located (Fig. 9).

In this region, at least one functional locus responsible for the statistical signal is a nonsynonymous (aspartic acid, Asp [D] to asparagine, Asn [N]; rs16969968) SNP at codon 398 of $C H R N A 5$. The Asn398 allele has been associated with nicotine dependence/heavy smoking, ${ }^{99,100}$ pleasurable response to smoking, ${ }^{101}$ smoking quantity, ${ }^{38}$ smoking persistence, increased susceptibility to develop lung cancer and vascular disease among smokers, ${ }^{38,103,104}$ serum cotinune levels among current smokers, ${ }^{105}$ and smoking cessation. ${ }^{106}$ According to a recent meta-analysis, each copy of the risk allele accounts only for approximately $0.5 \%$ of the variance in number of cigarettes smoked/day, reflecting the crude nature of the phenotype being studied ${ }^{107}$ (see Fig. 9C). Potentially explaining the neural pathways by which the Asp398Asn locus alters propensity to nicotine addiction, the Asn398 allele was found to predict the strength of a brain circuit connecting the anterior cingulate to the ventral striatum ${ }^{107}$ (Fig. 10A). The anterior cingulate is a component of the limbic system involved in emotional modulation, and the ventral striatum is a principle reward region of the brain. Strength of this circuit itself was associated with smoking status and severity of smoking (see Fig. 10B), and this genotype predicted the circuit strength in both smokers and nonsmokers. ${ }^{08}$

In vitro studies have shown that $(\alpha 4 \beta 2)_{2} a 5$ receptors that differed only by the asparagine 398 amino acid displayed altered response to nicotine agonist compared with receptors 
containing aspartic acid. ${ }^{109}$ Further studies showed that $A s n 398$ lowers Ca permeability and increases short-term desensitization in $(\alpha 4 \beta 2)_{2} a 5$, but does not alter the receptor sensitivity to activation. ${ }^{110}$

Other genetic loci implicated by GWAS in smoking behavior include the cyto chrome P450, family 2, subfamily A, polypeptide 6 (CYP2A6). The CYP2A6 enzyme converts nicotine to cotinine and accounts for $70 \%$ of initial nicotine metabolism. Functional polymorphisms within $C Y P 2 A 6$ have been associated with number of cigarette smoked per day. Variation within the dopamine $\beta$-hydroxylase $(D B H)$ gene has been associated with smoking cessation. ${ }^{111}$

For alcoholism, GWAS has been even less successful than for smoking. No alcohol dependence GWAS has yielded a finding of genome-wide significance. ${ }^{97-115} \mathrm{~A}$ large metaanalysis of GWAS on alcohol consumption was recently conducted in 12 population-based samples of European ancestry, totaling 26,316 individuals. The most significant associated marker, namely rs6943555, mapped to the autism susceptibility candidate 2 gene (AUTS2). Rs6943555 was found to moderate AUTS2 expression in human postmortem brain from the prefrontal cortex. Differences in expression of $A U T S 2$ were found in whole-brain extracts of mice selected for differences in voluntary alcohol consumption. ${ }^{116}$ Recently, multiple genome-wide significant loci for resting electroencephalogram (EEG) were identified by GWAS, ${ }^{117}$ illustrating the potential power of combining GWAS with the endophenotype strategy. GWAS of neuroimaging responses relevant to addiction such as those exploring impulsivity and reward are under way.

\section{Rare and Common Variants}

The focus of genetic studies of addiction, as well as other common disorders, has been common genetic variants with MAF greater than $1 \%$, and usually greater than $5 \%$. The idea behind these studies is the common disease/common variant $(\mathrm{CD} / \mathrm{CV})$ hypothesis according to which common alleles of ancient origin and with small to moderate effect lead to susceptibility to common disorders. However, recent evidence suggests that rare variants of stronger effect might substantially contribute to the genetic vulnerability to common diseases (for review see Ref. ${ }^{118}$ ). For schizophrenia and autism, multiple risk rare variants with moderate to large effect sizes have been already reported. ${ }^{119,120}$ Some of these variants appear to be associated with severe forms of disease and are thought to be of recent origin or de novo in sporadic cases. The contribution of rare variants in addictions is largely unknown. However, recent advances in sequencing technologies have opened the way for extensive searches for rare variants. The ability to detect and connect rare variants to behavior can be maximized by the study of genetically related individuals in families and founder populations that offers the advantage of reduced genetic and environmental heterogeneity as compared to mixed outbred populations and by sequencing individuals who are phenotypically extreme.

Rare genetic variants relevant to addiction have been found within the serotonin receptor $2 \mathrm{~B}$ gene (HTR2B) and MAOA, and several of the functional $C Y P 26$ alleles are also rare or uncommon. Both $H T R 2 B$ and $M A O A$ influence impulsivity and behavioral control and findings for these genes in humans remarkably parallel animal models.

$M A O A$ is an $\mathrm{X}$-linked gene encoding monoamine oxidase A, a mitochondrial enzyme that metabolizes monoamine neurotransmitters including norepinephrine, dopamine, and serotonin. MAOA knockout mice have higher levels of serotonin, norepinephrine, and to lesser extent dopamine, and manifest increased aggressive/impulsive behaviour and stress reactivity. ${ }^{121}$ In 1993, Brunner and colleagues ${ }^{122}$ reported a Dutch pedigree with eight males affected by borderline mental retardation and impulsive behaviors such as aggression, 
arson, attempted rape, fighting, and exhibitionism (Fig. 11A). Affected individuals were hemizygous for a stop-codon in the eighth exon of $M A O A$ leading to a complete and selective deficiency of MAOA activity. Consistently with an X-linked recessive pattern of transmission, heterozygous women were unaffected. This stop codon variant has not been found in other populations. More recently, a common $M A O A$ polymorphism influencing $M A O A$ transcription was discovered. ${ }^{123}$ This locus, termed the $M A O A$-linked polymorphic region $(M A O A-L P R)$, is a VNTR located approximately $1.2 \mathrm{~kb}$ upstream from the $M A O A$ start codon and within the gene's transcriptional control region ${ }^{123}$ (see Fig. 11B). Alleles at this VNTR have a different number of tandem copies of a 30-bp sequence, with the threeand four-repeat alleles being by far the most common. Alleles with four repeats are transcribed more efficiently than alleles with three copies, leading to higher $M A O A$ enzyme activity. ${ }^{123}$

Supporting the in vivo functional impact of this locus. $M A O A-L P R$ was found to predict serotonin $1 \mathrm{~A}$ receptor availability. ${ }^{124}$ In a longitudinally studied cohort of boys, Caspi and colleagues $^{125}$ found an interactive effect between $M A O A-L P R$ and childhood adversity on vulnerability to develop conduct disorder, an important risk factor for addiction. In this study, maltreated boys carrying the $M A O A$ low-activity genotype were more likely to develop antisocial problems than boys with the high-activity genotype. This result has been confirmed by a meta-analysis of eight independent studies. ${ }^{126}$ Results testing for $M A O A \times$ childhood adversity interaction in women are mixed. A recent study conducted in a sample of Native American women with extremely high rates of antisocial personality disorder and exposure to childhood adversity has reported results that parallel those observed in men. In this study, the effect of childhood sexual abuse on risk of developing alcoholism and antisocial personality disorder was influenced by $M A O A-L P R$ genotype ${ }^{40}$ Sexually abused women homozygous for the low-activity $M A O A-L P R$ allele had high rates of both disorders, and heterozygous women displayed an intermediate risk pattern. However, in the absence of childhood sexual abuse, there was no relationship between $M A O A$ genotype and these disorders.

Remarkably, and as was also the case with the serotonin transporter, an orthologous $M A O A$ VNTR is found in the rhesus macaque. As in humans, the lower activity allele predicts aggressive behavior in these animals, and the association is dependent on maternal separation. ${ }^{127}$

Interaction between $M A O A$ on risk for antisocial behavior and impulsivity has also been reported for testosterone ${ }^{128}$ and alcohol consumption. ${ }^{129,130}$

\section{HTR2B}

An $H T R 2 B$ stop codon was linked to severe impulsive aggression, ASPD, and alcoholism, with an effect that appeared to be modulated by stress, alcohol consumption, and hormones. Unlike the $M A O A$ stop codon, the $H T R 2 B$ stop codon is recurrent, being found in at least 100,000 individuals, but population-restricted.

The HTR2B gene, located on chromosome 2 (2q36.3-q37.1), encodes the sero tonin 2B receptor, a $G$ protein-coupled receptor. Serotonin $2 B$ receptors are widely expressed in the human brain. A rare $H T R 2 B$ variant, namely $Q 20^{*}$, is associated with severe impulsivity and criminal violence in the Finnish population. ${ }^{131}$ The stop codon has an allele frequency of $1.2 \%$ among Finns, but is specific to this founder. The variant was discovered by sequencing individuals displaying extremely severe impulsive and aggressive behavior. The sequencing sample consisted of population-matched controls and violent offenders who underwent psychiatric evaluation for the extreme nature of their crimes (homicides, assaults, arsons). The variant was enriched in individuals with a history of impulsive, 
nonpremeditated, violence. Carriers of the stop codon who had committed violent crimes did so while inebriated with alcohol, indicating that impulsive aggression could be the result of a $H T R 2 B$ stop codon by alcohol interaction. Carriers of the stop codon were cognitively within the normal range, except for a potential difference in working memory, which is known to reflect frontal lobe function. In line with studies on humans, mice with the htr $2 b$ gene knocked out were more novelty seeking and impulsive. For example, in a delay discounting task, $h t r 2 b^{-/-}$mice were less able to tolerate delay in order to receive a larger reward. ${ }^{131}$

\section{Classification and Treatment of Addictions}

Current nosology of addictions limits both clinicians and researchers. The diagnoses are syndromic (based on clusters of symptoms and clinical course rather than etiologically based). ${ }^{132}$ In addition, diagnoses are categorical, assuming a cutoff between normal and abnormal, although many of the problems associated with addiction are found in people who fall below the disease-associated threshold. ${ }^{133}$ As discussed, twin studies have detected evidence of etiologic factors shared with other psychiatric diseases ${ }^{28}$ and linking normal (personality) and abnormal variations (psychopathology). ${ }^{19,32}$ The identification of specific genes and environmental factors altering vulnerability and ability to recover would seem to represent a first step to develop an etiologically based nosology and to individualize treatment. In this reconceptualization of addiction, neuroimaging and neuropsychological measures would be combined with genotype to help define new diagnostic categories encom-passing both premordid vulnerability and addiction-induced neurobiologic change. Such a sea change in addiction diagnosis and management would require the collection of behavioral and genetic measures and their use against a research foundation that is today largely nonexistent. However, one of the first examples of pharmacogenetic prediction of treatment response in the addictions is a common functional missense variant of the $\mu$ opioid receptor (OPRM1 Asn4OAsp). As mentioned, this variant also appears to be associated with altered reward function. ${ }^{56}$ In several studies, naltrexone, a $\mu$-opioid receptor antagonist, was observed to augment abstinence and good therapeutic outcome in recovering alcoholics. Carriers of the $A s p 4 O$ allele were highly likely to show clinical improvement when treated with this drug. ${ }^{134,135}$ Similarly, CHRNA5Asn398Asp ${ }^{106}$ and DBH have been reported to influence smoking cessation treatment, and would seem to indicate the existence of subgroups of addicted patients identifiable via genetic testing.

\section{Summary}

Addictions are common, chronic, and relapsing diseases that develop through a multistep process. The impact of addictions on morbidity and mortality is high worldwide. Twin studies have shown that the heritability of addictions ranges from 0.39 (hallucinogens) to 0.72 (cocaine). Twin studies indicate that genes influence each stage from initiation to addiction, although the genetic determinants may differ. Addictions are by definition the result of gene $x$ environment interaction. These disorders, which are in part volitional, in part inborn, and in part determined by environmental experience, pose the full range of medical, genetic, policy, and moral challenges. Gene discovery is being facilitated by a variety of powerful approaches, but is in its infancy. It is not surprising that the genes discovered so far act in a variety of ways: via altered metabolism of drug (the alcohol and nicotine metabolic gene variants), via altered function of a drug receptor (the nicotinic receptor, which may alter affinity for nicotine but as discussed may also alter circuitry of reward), and via general mechanisms of addiction (genes such as monoamine oxidase A and the serotonin transporter that modulate stress response, emotion, and behavioral control). Addiction medicine today benefits from genetic studies that buttress the case for a neurobiologic origin of addictive behavior, and some general information on familially 
transmitted propensity that can be used to guide prevention. A few well-validated, specific predictors such as $O P R M 1, A D H 1 B, A L D H 2, C H R N A 5$, and $C Y P 26$ have been identified and can provide some specific guidance, for example, to understand alcohol-related flushing and upper GI cancer risk ( $A D H 1 B$ and $A K L D H 2)$, variation in nicotine metabolism (CYP26), and, potentially, naltrexone treatment response (OPRM1). However, the genetic predictors available are few in number and account for only a small portion of the genetic variance in liability, and have not been integrated into clinical nosology or care.

\section{References}

1. Reuter J, Raedler T, Rose M, et al. Pathological gambling is linked to reduced activation of the mesolimbic reward system. Nat Neurosci. 2005; 8(2):147-8. [PubMed: 15643429]

2. Merikangas KR, Avenevoli S. Implications of genetic epidemiology for the prevention of substance use disorders. Addict Behav. 2000; 25(6):807-20. [PubMed: 11125772]

3. Roberts AJ, Koob GF. The neurobiology of addiction: an overview. Alcohol Health Res World. 1997; 21(2):101-6. [PubMed: 15704343]

4. World Health Organization (WHO). [Accessed March 7, 2012] Management of substance abuse. Available at: http://www.who.int/substance_abuse/facts/alcohol/en/index.html

5. World Health Organization (WHO). [Accessed March 7, 2012] Management of substance abuse: the global burden. Available at: http://www.who.int/substance_abuse/facts/global_burden/en/

6. Office of National Drug Control Policy (ONDCP). [Accessed March 7, 2012] The economic costs of drug abuse in the United States 1992-1998. NCJ-190636. 2001. Available at: www.drugabuse.gov/about/welcome/aboutdrugabuse/magnitude

7. Bierut LJ, Dinwiddie SH, Begleiter H, et al. Familial transmission of substance dependence: alcohol, marijuana, cocaine, and habitual smoking: a report from the Collaborative Study on the Genetics of Alcoholism. Arch Gen Psychiatry. 1998; 55(11):982-8. [PubMed: 9819066]

8. Heath AC, Bucholz KK, Madden PA, et al. Genetic and environmental contributions to alcohol dependence risk in a national twin sample: consistency of findings in women and men. Psychol Med. 1997; 27(6):1381-96. [PubMed: 9403910]

9. Kendler KS, Karkowski L, Prescott CA. Hallucinogen, opiate, sedative and stimulant use and abuse in a population-based sample of female twins. Acta Psychiatr Scand. 1999; 99(5):368-76. [PubMed: 10353453]

10. Kendler KS, Karkowski LM, Neale MC, et al. Illicit psychoactive substance use, heavy use, abuse, and dependence in a US population-based sample of male twins. Arch Gen Psychiatry. 2000; 57(3):261-9. [PubMed: 10711912]

11. Kendler KS, Prescott CA. Caffeine intake, tolerance, and withdrawal in women: a populationbased twin study. Am J Psychiatry. 1999; 156(2):223-8. [PubMed: 9989558]

12. Li MD, Cheng R, Ma JZ, et al. A meta-analysis of estimated genetic and environ mental effects on smoking behavior in male and female adult twins. Addiction. 2003; 98(1):23-31. [PubMed: 12492752]

13. Tsuang MT, Lyons MJ, Eisen SA, et al. Genetic influences on DSM-III-R drug abuse and dependence: a study of 3,372 twin pairs. Am J Med Genet. 1996; 67(5):473-7. [PubMed: 8886164]

14. Goldman D, Oroszi G, Ducci F. The genetics of addictions: uncovering the genes. Nat Rev Genet. 2005; 6(7):521-32. [PubMed: 15995696]

15. Kendler KS, Karkowski LM, Corey LA, et al. Genetic and environmental risk factors in the aetiology of illicit drug initiation and subsequent misuse in women. Br J Psychiatry. 1999; 175:351-6. [PubMed: 10789303]

16. Thomasson HR, Edenberg HJ, Crabb DW, et al. Alcohol and aldehyde dehydro-genase genotypes and alcoholism in Chinese men. Am J Hum Genet. 1991; 48(4):677-81. [PubMed: 2014795]

17. Enoch MA, Gorodetsky E, Hodgkinson C, et al. Functional genetic variants that increase synaptic serotonin and 5-HT3 receptor sensitivity additively predict alcohol and drug dependence. Biol Psychiatry. 2010; 67(9):91s. 
18. Ducci F, Enoch MA, Yuan Q, et al. HTR3B is associated with alcoholism with antisocial behavior and alpha EEG power-an intermediate phenotype for alcohol ism and co-morbid behaviors. Alcohol. 2009; 43(1):73-84. [PubMed: 19185213]

19. Ducci F, Kaakinen M, Pouta A, et al. TTC12-ANKK1-DRD2 and CHRNA5- CHRNA3CHRNB4 influence different pathways leading to smoking behavior from adolescence to midadulthood. Biol Psychiatry. 2011; 69(7):650-60. [PubMed: 21168125]

20. Ripatti S, Tikkanen E, Orho-Melander M, et al. A multilocus genetic risk score for coronary heart disease: case-control and prospective cohort analyses. Lancet. 2010; 376(9750):1393-400. [PubMed: 20971364]

21. Kendler KS, Schmitt E, Aggen SH, et al. Genetic and environmental influences on alcohol, caffeine, cannabis, and nicotine use from early adolescence to middle adulthood. Arch Gen Psychiatry. 2008; 65(6):674-82. [PubMed: 18519825]

22. Kendler KS, Jacobson KC, Gardner CO, et al. Creating a social world: a developmental twin study of peer-group deviance. Arch Gen Psychiatry. 2007; 64(8):958-65. [PubMed: 17679640]

23. Grant BF, Stinson FS, Dawson DA, et al. Co-occurrence of 12-month alcohol and drug use disorders and personality disorders in the United States: results from the National Epidemiologic Survey on Alcohol and Related Conditions. Arch Gen Psychiatry. 2004; 61(4):361-8. [PubMed: 15066894]

24. Grant BF, Stinson FS, Dawson DA, et al. Prevalence and co-occurrence of sub stance use disorders and independent mood and anxiety disorders: results from the National Epidemiologic Survey on Alcohol and Related Conditions. Arch Gen Psychiatry. 2004; 61(8):807-16. [PubMed: 15289279]

25. Kessler RC, Crum RM, Warner LA, et al. Lifetime co-occurrence of DSM-III-R alcohol abuse and dependence with other psychiatric disorders in the National Comorbidity Survey. Arch Gen Psychiatry. 1997; 54(4):313-21. [PubMed: 9107147]

26. Goldman D, Bergen A. General and specific inheritance of substance abuse and alcoholism. Arch Gen Psychiatry. 1998; 55(11):964-5. [PubMed: 9819063]

27. Hicks BM, Krueger RF, Iacono WG, et al. Family transmission and heritability of externalizing disorders: a twin-family study. Arch Gen Psychiatry. 2004; 61(9):922-8. [PubMed: 15351771]

28. Kendler KS, Prescott CA, Myers J, et al. The structure of genetic and environmental risk factors for common psychiatric and substance use disorders in men and women. Arch Gen Psychiatry. 2003; 60(9):929-37. [PubMed: 12963675]

29. Han C, McGue MK, Iacono WG. Lifetime tobacco, alcohol and other substance use in adolescent Minnesota twins: univariate and multivariate behavioral genetic analyses. Addiction. 1999; 94(7): 981-93. [PubMed: 10707437]

30. Kendler KS, Myers J, Prescott CA. Specificity of genetic and environmental risk factors for symptoms of cannabis, cocaine, alcohol, caffeine, and nicotine dependence. Arch Gen Psychiatry. 2007; 64(11):1313-20. [PubMed: 17984400]

31. Ducci F, Enoch MA, Funt S, et al. Increased anxiety and other similarities in temperament of alcoholics with and without antisocial personality disorder across three diverse populations. Alcohol. 2007; 41(1):3-12. [PubMed: 17452294]

32. Krueger RF, Hicks BM, Patrick CJ, et al. Etiologic connections among substance dependence, antisocial behavior, and personality: modeling the externalizing spectrum. J Abnorm Psychol. 2002; 111(3):411-24. [PubMed: 12150417]

33. Sher KJ, Bartholow BD, Wood MD. Personality and substance use disorders: a prospective study. J Consult Clin Psychol. 2000; 68(5):818-29. [PubMed: 11068968]

34. Kendler KS, Heath AC, Neale MC, et al. Alcoholism and major depression in women. A twin study of the causes of comorbidity. Arch Gen Psychiatry. 1993; 50(9):690-8. [PubMed: 8357294]

35. Prescott CA, Aggen SH, Kendler KS. Sex-specific genetic influences on the comorbidity of alcoholism and major depression in a population-based sample of US twins. Arch Gen Psychiatry. 2000; 57(8):803-11. [PubMed: 10920470]

36. Zimmermann P, Wittchen HU, Hofler M, et al. Primary anxiety disorders and the development of subsequent alcohol use disorders: a 4-year community study of adolescents and young adults. Psychol Med. 2003; 33(7):1211-22. [PubMed: 14580076] 
37. Ducci F, Roy A, Shen PH, et al. Association of substance use disorders with childhood trauma but not African genetic heritage in an African American cohort. Am J Psychiatry. 2009; 166(9):103140. [PubMed: 19605534]

38. Thorgeirsson TE, Geller F, Sulem P, et al. A variant associated with nicotine dependence, lung cancer and peripheral arterial disease. Nature. 2008; 452(7187):638-42. [PubMed: 18385739]

39. Caspi A, Moffitt TE. Gene-environment interactions in psychiatry: joining forces with neuroscience. Nat Rev Neurosci. 2006; 7(7):583-90. [PubMed: 16791147]

40. Ducci F, Enoch MA, Hodgkinson C, et al. Interaction between a functional MAOA locus and childhood sexual abuse predicts alcoholism and antisocial personality disorder in adult women. Mol Psychiatry. 2008; 13(3):334-47. [PubMed: 17592478]

41. Hariri AR, Mattay VS, Tessitore A, et al. Serotonin transporter genetic variation and the response of the human amygdala. Science. 2002; 297(5580):400-3. [PubMed: 12130784]

42. Zubieta JK, Heitzeg MM, Smith YR, et al. COMT val158met genotype affects mu-opioid neurotransmitter responses to a pain stressor. Science. 2003; 299(5610):1240-3. [PubMed: 12595695]

43. Zhou Z, Zhu G, Hariri AR, et al. Genetic variation in human NPY expression affects stress response and emotion. Nature. 2008; 452(7190):997-1001. [PubMed: 18385673]

44. Binder EB, Bradley RG, Liu W, et al. Association of FKBP5 polymorphisms and childhood abuse with risk of posttraumatic stress disorder symptoms in adults. JAMA. 2008; 299(11):1291-305. [PubMed: 18349090]

45. Desrivieres S, Lourdusamy A, Muller C, et al. Glucocorticoid receptor (NR3C1) gene polymorphisms and onset of alcohol abuse in adolescents. Addict Biol. 16(3):510-3. [PubMed: 20731635]

46. Ressler KJ, Mercer KB, Bradley B, et al. Post-traumatic stress disorder is associated with PACAP and the PAC1 receptor. Nature. 2011; 470(7335):492-7. [PubMed: 21350482]

47. Goldman D, Ducci F. Deconstruction of vulnerability to complex diseases: enhanced effect sizes and power of intermediate phenotypes. Scientific World Journal Review. 2007; 2(7):124-30.

48. Heath AC, Madden PA, Bucholz KK, et al. Genetic differences in alcohol sensitivity and the inheritance of alcoholism risk. Psychol Med. 1999; 29(5):1069-81. [PubMed: 10576299]

49. Rodriguez LA, Wilson JR, Nagoshi CT. Does psychomotor sensitivity to alcohol predict subsequent alcohol use? Alcohol Clin Exp Res. 1993; 17(1):155-61. [PubMed: 8452197]

50. Schuckit MA, Smith TL, Kalmijn J, et al. Response to alcohol in daughters of alcoholics: a pilot study and a comparison with sons of alcoholics. Alcohol Alcohol. 2000; 35(3):242-8. [PubMed: 10869242]

51. Schuckit MA. Biological, psychological and environmental predictors of the alcohol ism risk: a longitudinal study. J Stud Alcohol. 1998; 59(5):485-94. [PubMed: 9718100]

52. Hu X, Oroszi G, Chun J, et al. An expanded evaluation of the relationship of four alleles to the level of response to alcohol and the alcoholism risk. Alcohol Clin Exp Res. 2005; 29(1):8-16. [PubMed: 15654286]

53. Meyer-Lindenberg A, Weinberger DR. Intermediate phenotypes and genetic mechanisms of psychiatric disorders. Nat Rev Neurosci. 2006; 7(10):818-27. [PubMed: 16988657]

54. Hariri AR, Drabant EM, Munoz KE, et al. A susceptibility gene for affective disorders and the response of the human amygdala. Arch Gen Psychiatry. 2005; 62(2):146-52. [PubMed: 15699291]

55. Peters J, Bromberg U, Schneider S, et al. Lower ventral striatal activation during reward anticipation in adolescent smokers. Am J Psychiatry. 2011; 168(5):540-9. [PubMed: 21362742]

56. Ramchandani VA, Umhau J, Pavon FJ, et al. A genetic determinant of the striatal dopamine response to alcohol in men. Mol Psychiatry. 2011; 16(8):809-17. [PubMed: 20479755]

57. Ducci F, Goldman D. Genetic approaches to addiction: genes and alcohol. Addiction. 2008; 103(9):1414-28. [PubMed: 18422824]

58. Brooks PJ, Goldman D, Li TK. Alleles of alcohol and acetaldehyde metabolism genes modulate susceptibility to oesophageal cancer from alcohol consumption. Hum Genomics. 2009; 3(2):1035. [PubMed: 19164087] 
59. Bierut LJ, Goate AM, Breslau N, et al. ADH1B is associated with alcohol dependence and alcohol consumption in populations of European and African ancestry. Mol Psychiatry. 2012; 17(4):44550. [PubMed: 21968928]

60. Goldman D, Enoch MA. Genetic epidemiology of ethanol metabolic enzymes: a role for selection. World Rev Nutr Diet. 1990; 63:143-60. [PubMed: 2197794]

61. Lewis DA, Melchitzky DS, Sesack SR, et al. Dopamine transporter immunoreactivity in monkey cerebral cortex: regional, laminar, and ultrastructural localization. J Comp Neurol. 2001; 432(1): 119-36. [PubMed: 11241381]

62. Mazei MS, Pluto CP, Kirkbride B, et al. Effects of catecholamine uptake blockers in the caudateputamen and subregions of the medial prefrontal cortex of the rat. Brain Res. 2002; 936(1-2):5867. [PubMed: 11988230]

63. Giakoumaki SG, Roussos P, Bitsios P. Improvement of prepulse inhibition and executive function by the COMT inhibitor tolcapone depends on COMT Val158Met polymorphism. Neuropsychopharmacology. 2008; 33(13):3058-68. [PubMed: 18536698]

64. Yavich L, Forsberg MM, Karayiorgou M, et al. Site-specific role of catechol-O-methyltransferase in dopamine overflow within prefrontal cortex and dorsal striatum. J Neurosci. 2007; 27(38): 10196-209. [PubMed: 17881525]

65. Jeffery DR, Roth JA. Characterization of membrane-bound and soluble catechol-Omethyltransferase from human frontal cortex. J Neurochem. 1984; 42(3):826-32. [PubMed: 6693904]

66. Rivett AJ, Francis A, Roth JA. Distinct cellular localization of membrane-bound and soluble forms of catechol-O-methyltransferase in brain. J Neurochem. 1983; 40(1):215-9. [PubMed: 6848660]

67. Chen J, Song J, Yuan P, et al. Orientation and cellular distribution of membrane-bound catechol-Omethyltransferase in cortical neurons: implications for drug development. J Biol Chem. 2011; 286(40):34752-60. [PubMed: 21846718]

68. Lachman HM, Papolos DF, Saito T, et al. Human catechol-O-methyltransferase pharmacogenetics: description of a functional polymorphism and its potential application to neuropsychiatric disorders. Pharmacogenetics. 1996; 6(3):243-50. [PubMed: 8807664]

69. Scanlon PD, Raymond FA, Weinshilboum RM. Catechol-O-methyltransferase: thermolabile enzyme in erythrocytes of subjects homozygous for allele for low activity. Science. 1979; 203(4375):63-5. [PubMed: 758679]

70. Weinshilboum R, Dunnette J. Thermal stability and the biochemical genetics of erythrocyte catechol-O-methyl-transferase and plasma dopamine-beta-hydroxy-lase. Clin Genet. 1981; 19(5): 426-37. [PubMed: 7296933]

71. Chen J, Lipska BK, Halim N, et al. Functional analysis of genetic variation in catechol-Omethyltransferase (COMT): effects on mRNA, protein, and enzyme activity in postmortem human brain. Am J Hum Genet. 2004; 75(5):807-21. [PubMed: 15457404]

72. Egan MF, Goldberg TE, Kolachana BS, et al. Effect of COMT Val108/158 Met genotype on frontal lobe function and risk for schizophrenia. Proc Natl Acad Sci U S A. 2001; 98(12):6917-22. [PubMed: 11381111]

73. Goldberg TE, Egan MF, Gscheidle T, et al. Executive sub processes in working memory: relationship to catechol-O-methyltransferase Val158Met genotype and schizophrenia. Arch Gen Psychiatry. 2003; 60(9):889-96. [PubMed: 12963670]

74. Malhotra AK, Kestler LJ, Mazzanti C, et al. A functional polymorphism in the COMT gene and performance on a test of prefrontal cognition. Am J Psychiatry. 2002; 159(4):652-4. [PubMed: 11925305]

75. Gogos JA, Morgan M, Luine V, et al. Catechol-O-methyltransferase-deficient mice exhibit sexually dimorphic changes in catecholamine levels and behavior. Proc Natl Acad Sci U S A. 1998; 95(17):9991-6. [PubMed: 9707588]

76. Enoch MA, Xu K, Ferro E, et al. Genetic origins of anxiety in women: a role for a functional catechol-O-methyltransferase polymorphism. Psychiatr Genet. 2003; 13(1):33-41. [PubMed: 12605099]

77. Jiang H, Xie T, Ramsden DB, et al. Human catechol-O-methyltransferase down-regulation by estradiol. Neuropharmacology. 2003; 45(7):1011-8. [PubMed: 14573393] 
78. Diatchenko L, Slade GD, Nackley AG, et al. Genetic basis for individual variations in pain perception and the development of a chronic pain condition. Hum Mol Genet. 2005; 14(1):135-43. [PubMed: 15537663]

79. Smolka MN, Schumann G, Wrase J, et al. Catechol-O-methyltransferase val158met genotype affects processing of emotional stimuli in the amygdala and prefrontal cortex. J Neurosci. 2005; 25(4):836-42. [PubMed: 15673663]

80. Tammimaki AE, Mannisto PT. Are genetic variants of COMT associated with addiction? Pharmacogenet Genomics. 2010; 20(12):717-41. [PubMed: 20975619]

81. Vandenbergh DJ, Rodriguez LA, Miller IT, et al. High-activity catechol-O-methyl-transferase allele is more prevalent in polysubstance abusers. Am J Med Genet. 1997; 74(4):439-42. [PubMed: 9259381]

82. Jugurnauth SK, Chen CK, Barnes MR, et al. A COMT gene haplotype associated with methamphetamine abuse. Pharmacogenet Genomics. 2011; 21(11):731-40. [PubMed: 21934638]

83. Tiihonen J, Hallikainen T, Lachman H, et al. Association between the functional variant of the catechol-O-methyltransferase (COMT) gene and type 1 alcoholism. Mol Psychiatry. 1999; 4(3): 286-9. [PubMed: 10395222]

84. Kauhanen J, Hallikainen T, Tuomainen TP, et al. Association between the functional polymorphism of catechol-O-methyltransferase gene and alcohol consumption among social drinkers. Alcohol Clin Exp Res. 2000; 24(2):135-9. [PubMed: 10698363]

85. Lesch KP, Bengel D, Heils A, et al. Association of anxiety-related traits with a polymorphism in the serotonin transporter gene regulatory region. Science. 1996; 274(5292):1527-31. [PubMed: 8929413]

86. Hu XZ, Lipsky RH, Zhu G, et al. Serotonin transporter promoter gain-of-function genotypes are linked to obsessive-compulsive disorder. Am J Hum Genet. 2006; 78(5):815-26. [PubMed: 16642437]

87. Little KY, McLauglin DP, Ranc J, et al. Serotonin transporter binding sites and mRNA levels in depressed persons committing suicide. Biol Psychiatry. 1997; 41(12):1156-64. [PubMed: 9171906]

88. Heinz A, Jones DW, Mazzanti C, et al. A relationship between serotonin transporter genotype and in vivo protein expression and alcohol neurotoxicity. Biol Psychiatry. 2000; 47(7):643-9. [PubMed: 10745057]

89. Shioe K, Ichimiya T, Suhara T, et al. No association between genotype of the promoter region of serotonin transporter gene and serotonin transporter binding in human brain measured by PET. Synapse. 2003; 48(4):184-8. [PubMed: 12687637]

90. Caspi A, Sugden K, Moffitt TE, et al. Influence of life stress on depression: moderation by a polymorphism in the 5-HTT gene. Science. 2003; 301(5631):386-9. [PubMed: 12869766]

91. Risch N, Herrell R, Lehner T, et al. Interaction between the serotonin transporter gene (5HTTLPR), stressful life events, and risk of depression: a meta-analysis. JAMA. 2009; 301(23): 2462-71. [PubMed: 19531786]

92. Szekely E, Herba CM, Arp PP, et al. Recognition of scared faces and the serotonin transporter gene in young children: the Generation R Study. J Child Psychol Psychiatry. 2011; 52(12):1279-86. [PubMed: 21864315]

93. Pezawas L, Meyer-Lindenberg A, Drabant EM, et al. 5-HTTLPR polymorphism impacts human cingulate-amygdala interactions: a genetic susceptibility mechanism for depression. Nat Neurosci. 2005; 8(6):828-34. [PubMed: 15880108]

94. Heinz A, Braus DF, Smolka MN, et al. Amygdala-prefrontal coupling depends on a genetic variation of the serotonin transporter. Nat Neurosci. 2005; 8(1):20-1. [PubMed: 15592465]

95. Mueller A, Armbruster D, Moser DA, et al. Interaction of serotonin transporter gene-linked polymorphic region and stressful life events predicts cortisol stress response. Neuropsychopharmacology. 2011; 36(7):1332-9. [PubMed: 21368747]

96. Barr CS, Newman TK, Becker ML, et al. The utility of the non-human primate: model for studying gene by environment interactions in behavioral research. Genes Brain Behav. 2003; 2(6):336-40. [PubMed: 14653305] 
97. Barr CS, Newman TK, Lindell S, et al. Interaction between serotonin transporter gene variation and rearing condition in alcohol preference and consumption in female primates. Arch Gen Psychiatry. 2004; 61(11):1146-52. [PubMed: 15520362]

98. Berrettini W, Yuan X, Tozzi F, et al. Alpha-5/alpha-3 nicotinic receptor subunit alleles increase risk for heavy smoking. Mol Psychiatry. 2008; 13(4):368-73. [PubMed: 18227835]

99. Bierut LJ, Madden PA, Breslau N, et al. Novel genes identified in a high-density genome wide association study for nicotine dependence. Hum Mol Genet. 2007; 16(1):24-35. [PubMed: 17158188]

100. Saccone SF, Hinrichs AL, Saccone NL, et al. Cholinergic nicotinic receptor genes implicated in a nicotine dependence association study targeting 348 candidate genes with 3713 SNPs. Hum Mol Genet. 2007; 16(1):36-49. [PubMed: 17135278]

101. Sherva R, Wilhelmsen K, Pomerleau CS, et al. Association of a single nucleotide polymorphism in neuronal acetylcholine receptor subunit alpha 5 (CHRNA5) with smoking status and with 'pleasurable buzz' during early experimentation with smoking. Addiction. 2008; 103(9):154452. [PubMed: 18783506]

102. Stevens VL, Bierut LJ, Talbot JT, et al. Nicotinic receptor gene variants influence susceptibility to heavy smoking. Cancer Epidemiol Biomarkers Prev. 2008; 17(12):3517-25. [PubMed: 19029397]

103. Amos CI, Wu X, Broderick P, et al. Genome-wide association scan of tag SNPs identifies a susceptibility locus for lung cancer at 15q25. 1 Nat Genet. 2008; 40(5):616-22. [PubMed: 18385676]

104. Hung RJ, McKay JD, Gaborieau V, et al. A susceptibility locus for lung cancer maps to nicotinic acetylcholine receptor subunit genes on 15q25. Nature. 2008; 452(7187):633-7. [PubMed: 18385738]

105. Timofeeva MN, McKay JD, Smith GD, et al. Genetic polymorphisms in 15q25 and 19q13 loci, cotinine levels, and risk of lung cancer in EPIC. Cancer Epidemiol Biomarkers Prev. 2011; 20(10):2250-61. [PubMed: 21862624]

106. Munafo MR, Johnstone EC, Walther D, et al. CHRNA3 rs1051730 genotype and short-term smoking cessation. Nicotine Tob Res. 2011; 13(10):982-8. [PubMed: 21690317]

107. Neiswanger K, Hill SY, Kaplan BB. Association and linkage studies of the TAQI A1 allele at the dopamine D2 receptor gene in samples of female and male alcoholics. Am J Med Genet. 1995; 60(4):267-71. [PubMed: 7485259]

108. Hong LE, Hodgkinson CA, Yang Y, et al. A genetically modulated, intrinsic cingulate circuit supports human nicotine addiction. Proc Natl Acad Sci U S A. 2010; 107(30):13509-14. [PubMed: 20643934]

109. Bierut LJ, Stitzel JA, Wang JC, et al. Variants in nicotinic receptors and risk for nicotine dependence. Am J Psychiatry. 2008; 165(9):1163-71. [PubMed: 18519524]

110. Kuryatov A, Berrettini W, Lindstrom J. Acetylcholine receptor (AChR) alpha5 subunit variant associated with risk for nicotine dependence and lung cancer reduces (alpha4beta2)alpha5 AChR function. Mol Pharmacol. 2011; 79(1):119-25. [PubMed: 20881005]

111. Thorgeirsson TE, Gudbjartsson DF, Surakka I, et al. Sequence variants at CHRNB3- CHRNA6 and CYP2A6 affect smoking behavior. Nat Genet. 2010; 42(5):448-53. [PubMed: 20418888]

112. Treutlein J, Cichon S, Ridinger M, et al. Genome-wide association study of alcohol dependence. Arch Gen Psychiatry. 2009; 66(7):773-84. [PubMed: 19581569]

113. Lind PA, Macgregor S, Vink JM, et al. A genome wide association study of nicotine and alcohol dependence in Australian and Dutch populations. Twin Res Hum Genet. 2010; 13(1):10-29. [PubMed: 20158304]

114. Bierut LJ, Agrawal A, Bucholz KK, et al. A genome-wide association study of alcohol dependence. Proc Natl Acad Sci U S A. 2010; 107(11):5082-7. [PubMed: 20202923]

115. Edenberg HJ, Koller DL, Xuei X, et al. Genome-wide association study of alcohol dependence implicates a region on chromosome 11. Alcohol Clin Exp Res. 2010; 34(5):840-52. [PubMed: 20201924] 
116. Schumann G, Coin LJ, Lourdusamy A, et al. Genome-wide association and genetic functional studies identify autism susceptibility candidate 2 gene (AUTS2) in the regulation of alcohol consumption. Proc Natl Acad Sci U S A. 2011; 108(17):7119-24. [PubMed: 21471458]

117. Hodgkinson CA, Enoch MA, Srivastava V, et al. Genome-wide association identifies candidate genes that influence the human electroencephalogram. Proc Natl Acad Sci U S A. 2010; 107(19): 8695-700. [PubMed: 20421487]

118. Uher R. The role of genetic variation in the causation of mental illness: an evolution-informed framework. Mol Psychiatry. 2009; 14(12):1072-82. [PubMed: 19704409]

119. Sebat J, Lakshmi B, Malhotra D, et al. Strong association of de novo copy number mutations with autism. Science. 2007; 316(5823):445-9. [PubMed: 17363630]

120. Stefansson H, Rujescu D, Cichon S, et al. Large recurrent microdeletions associated with schizophrenia. Nature. 2008; 455(7210):232-6. [PubMed: 18668039]

121. Cases O, Seif I, Grimsby J, et al. Aggressive behavior and altered amounts of brain serotonin and norepinephrine in mice lacking MAOA. Science. 1995; 268(5218):1763-6. [PubMed: 7792602]

122. Brunner HG, Nelen M, Breakefield XO, et al. Abnormal behavior associated with a point mutation in the structural gene for monoamine oxidase A. Science. 1993; 262(5133):578-80. [PubMed: 8211186]

123. Sabol SZ, Hu S, Hamer D. A functional polymorphism in the monoamine oxidase A gene promoter. Hum Genet. 1998; 103(3):273-9. [PubMed: 9799080]

124. Mickey BJ, Ducci F, Hodgkinson CA, et al. Monoamine oxidase A genotype predicts human serotonin 1A receptor availability in vivo. J Neurosci. 2008; 28(44):11354-9. [PubMed: 18971477]

125. Caspi A, McClay J, Moffitt TE, et al. Role of genotype in the cycle of violence in maltreated children. Science. 2002; 297(5582):851-4. [PubMed: 12161658]

126. Taylor A, Kim-Cohen J. Meta-analysis of gene-environment interactions in develop mental psychopathology. Dev Psychopathol. 2007; 19(4):1029-37. [PubMed: 17931432]

127. Newman TK, Syagailo YV, Barr CS, et al. Monoamine oxidase A gene promoter variation and rearing experience influences aggressive behavior in rhesus monkeys. Biol Psychiatry. 2005; 57(2):167-72. [PubMed: 15652876]

128. Sjoberg RL, Ducci F, Barr CS, et al. A non-additive interaction of a functional MAO-A VNTR and testosterone predicts antisocial behavior. Neuropsychopharmacology. 2008; 33(2):425-30. [PubMed: 17429405]

129. Tikkanen R, Sjoberg RL, Ducci F, et al. Effects of MAOA-genotype, alcohol consumption, and aging on violent behavior. Alcohol Clin Exp Res. 2009; 33(3):428-34. [PubMed: 19120058]

130. Tikkanen R, Ducci F, Goldman D, et al. MAOA alters the effects of heavy drinking and childhood physical abuse on risk for severe impulsive acts of violence among alcoholic violent offenders. Alcohol Clin Exp Res. 2010; 34(5):853-60. [PubMed: 20201935]

131. Bevilacqua L, Doly S, Kaprio J, et al. A population-specific HTR2B stop codon predisposes to severe impulsivity. Nature. 2010; 468(7327):1061-6. [PubMed: 21179162]

132. Kupfer, DJ.; First, MB.; Regier, DA., editors. A research agenda for DSM-V. Washington, DC: American Psychiatric Association; 2002.

133. Caetano R, Cunradi C. Alcohol dependence: a public health perspective. Addiction. 2002; 97(6): 633-45. [PubMed: 12084125]

134. Anton RF, Oroszi G, O'Malley S, et al. An evaluation of mu-opioid receptor (OPRM1) as a predictor of naltrexone response in the treatment of alcohol dependence: results from the Combined Pharmacotherapies and Behavioral Interventions for Alcohol Dependence (COMBINE) study. Arch Gen Psychiatry. 2008; 65(2):135-44. [PubMed: 18250251]

135. Oslin DW, Berrettini W, Kranzler HR, et al. A functional polymorphism of the mu-opioid receptor gene is associated with naltrexone response in alcohol-dependent patients. Neuropsychopharmacology. 2003; 28(8):1546-52. [PubMed: 12813472] 


\section{Key Points}

- Addictive disorders are etiologically complex conditions that result from multiple genetic and environmental risk factors. Heritability estimates for addictions range between 0.4 (hallucinogens) to 0.7 (cocaine).

- Genetic and environmental influences modulating risk of substance use disorders change developmentally and across the lifespan.

- Genes involved in vulnerability to addictions include both substance-specific genes and genes that act on common pathways involved in addiction to different agents and propensity to other psychiatric disorders. Substance-specific genes include genes for metabolic enzymes involved in the metabolism of the substance (eg, ALDH2, ADH1B for alcohol) as well as genes encoding gatekeeper molecules such as drug receptors (eg, nicotinic receptors, OPRM1).

- Genes influencing diverse aspects of addiction neurobiology including anxiety, impulsiv-ity, and reward, including genes such as monoamine oxidase A (MAOA), the serotonin transporter (SLC6A4) and catechol-Omethyl transferase (COMT), have been implicated in the shared genetic liability between addictions and other psychiatric diseases.

- At this early stage at which genome-wide association studies have primarily been applied to relatively small addiction samples, more than $95 \%$ of the genetic variance remains unaccounted for, indicating that most of the genetic risk factors for addiction have not been discovered yet.

- The identification of the genetic determinants of addiction is important to improve our ability to predict risk, predict treatment response, develop new treatments, and under stand better the effects of the environment. This potential is already exemplified by the use of an OPRM1 variant to predict treatment response to naltrexone in alcoholism. 


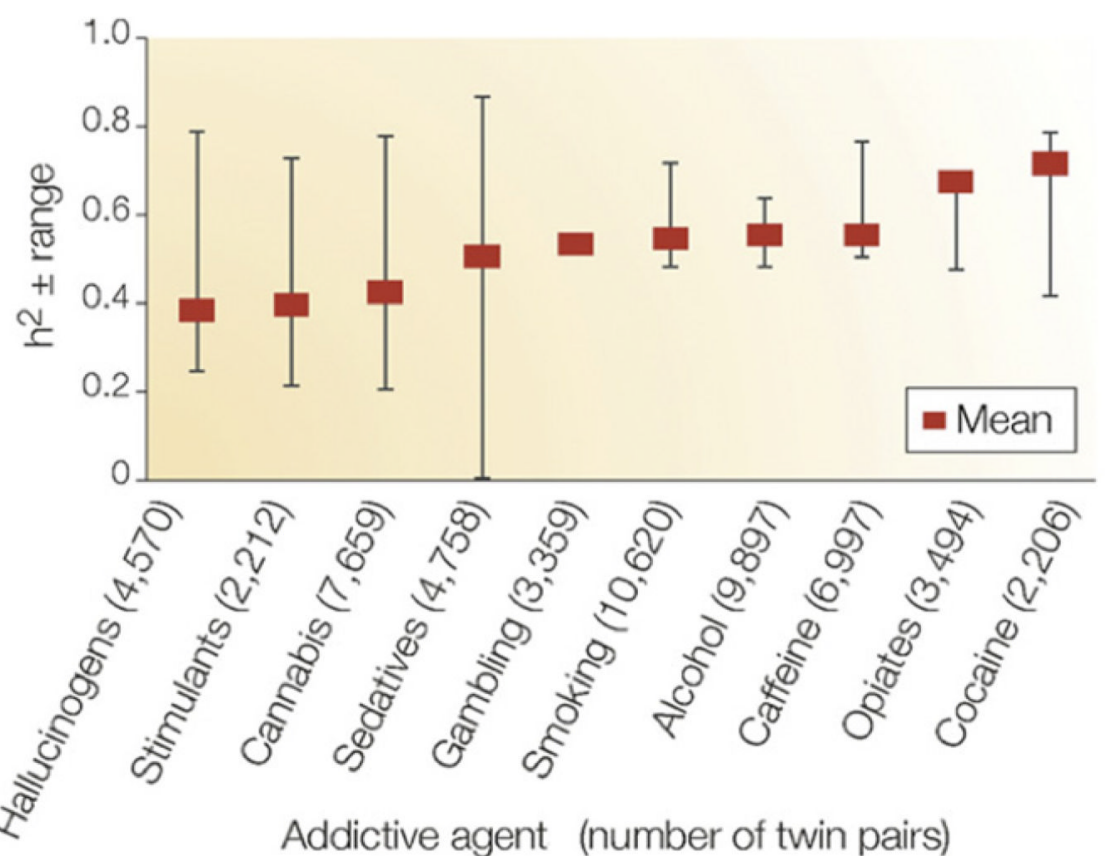

Fig. 1.

Heritability (weighted means and ranges) of 10 addictive disorders: hallucinogens, cannabis, stimulants, sedatives, opiates, and cocaine dependence or abuse; alcohol dependence; smoking; caffeine consumption or heavy use; pathologic gambling. Weighted heritability $\left(h^{2}\right)$ means were computed using data from large surveys of adult twins. (Adapted from Goldman D, Oroszi G, Ducci F. The genetics of addictions: uncovering the genes. Nat Rev Genet 2005;6(7):521-32.) 


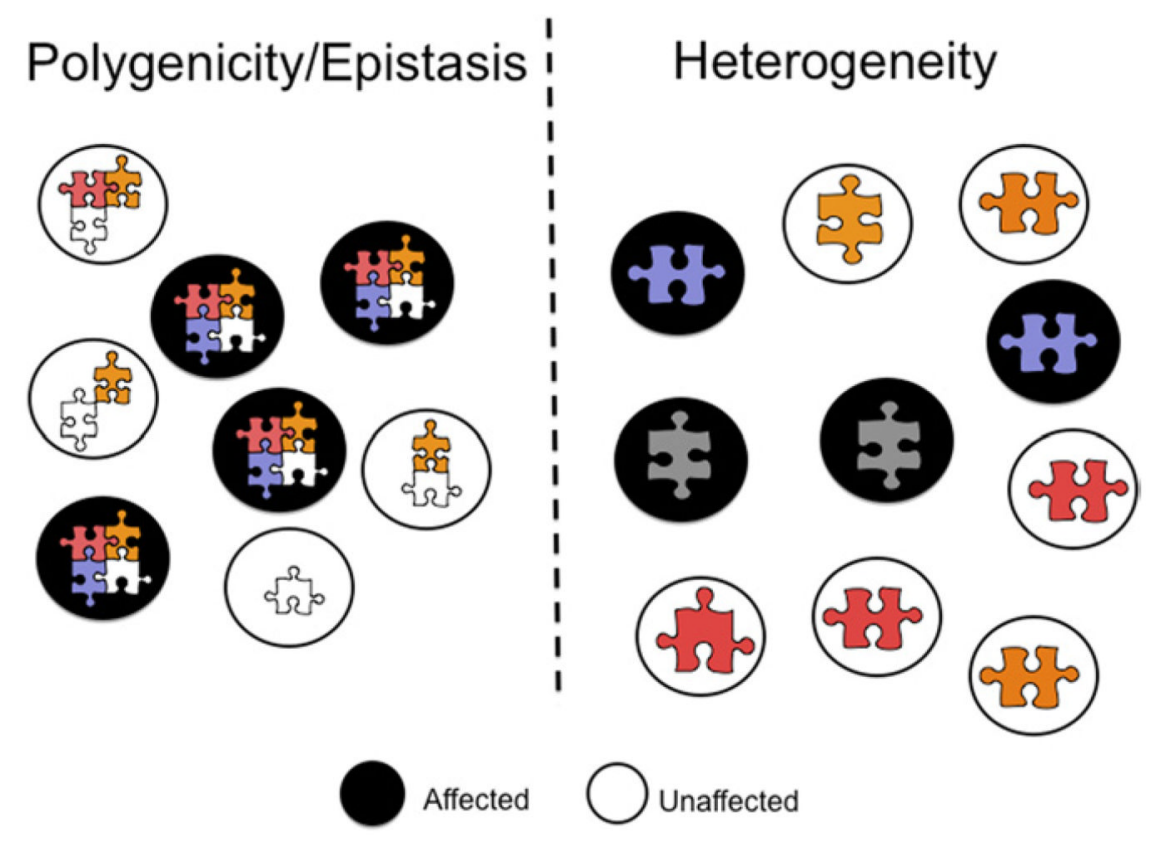

Fig. 2.

Genetic complexity in unrelated individuals: epistasis and heterogeneity. Each risk allele is represented as a puzzle piece of different color or shape. Black circles indicate affected individuals and empty circles denote unaffected individuals. (Adapted from Gold man D, Oroszi G, Ducci F. The genetics of addictions: uncovering the genes. Nat Rev Genet 2005;6(7):521-32.) 

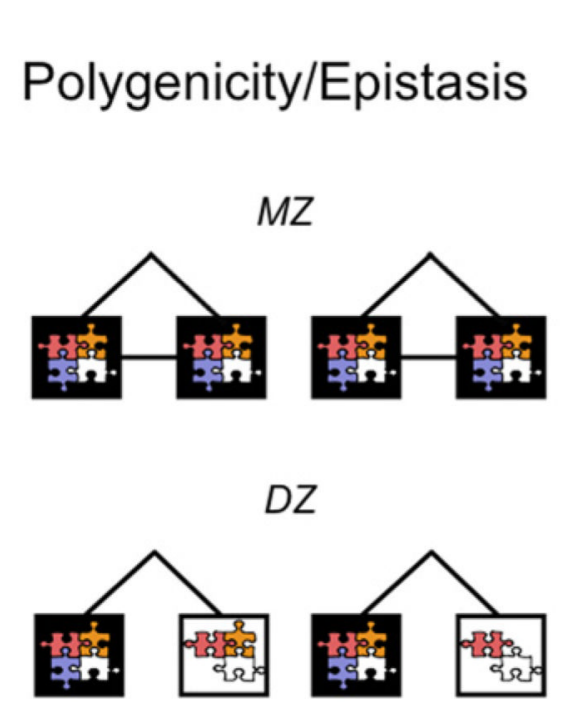

Affected

\section{1}

Heterogeneity

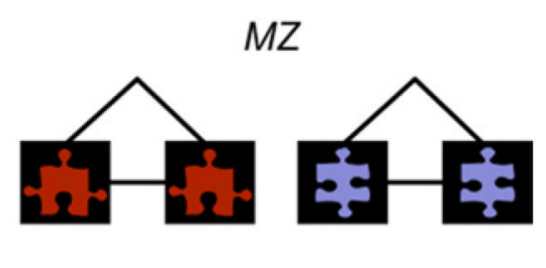

$D Z$

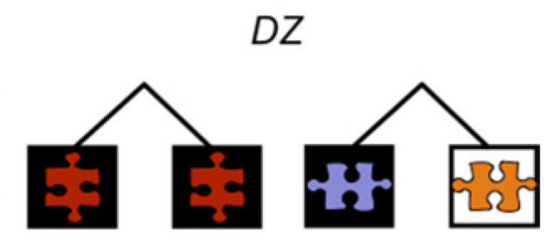

Fig. 3.

Genetic complexity and twin concordance: epistasis and heterogeneity. Each risk allele is represented as a puzzle piece of different color or shape. Members of twin pairs are represented by squares. Black squares indicate affected individuals and empty squares denote unaffected individuals. (Adapted from Goldman D, Oroszi G, Ducci F. The genetics of addictions: uncovering the genes. Nat Rev Genet 2005;6(7):521-32.) 


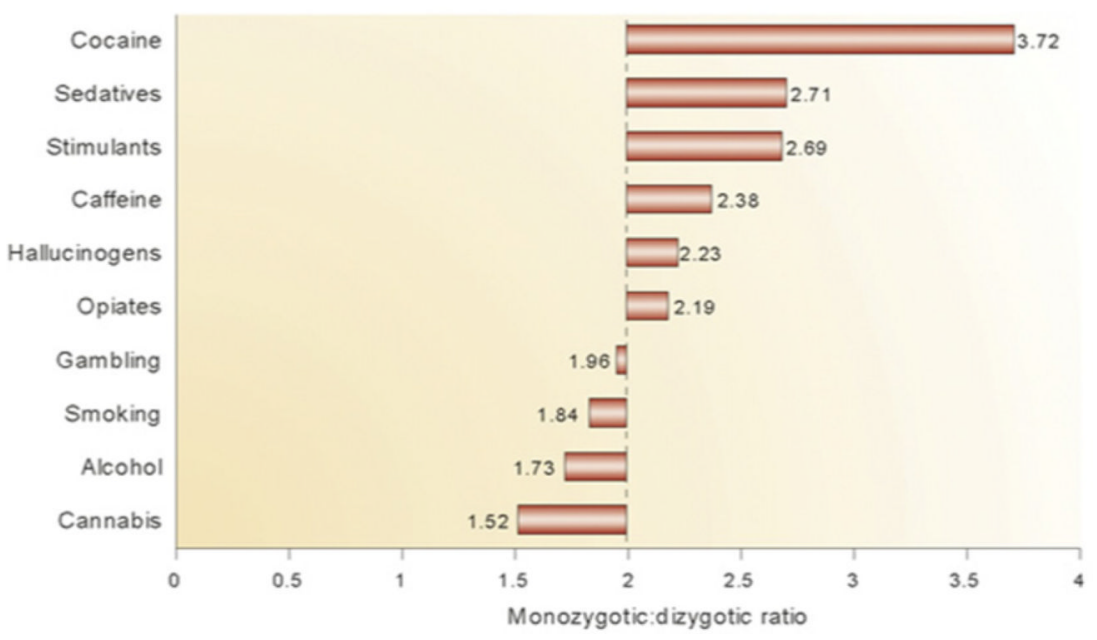

Fig. 4.

MZ/DZ twin concordance ratios for 10 addictions. MZ/DZ ratios tend to converge on two, inconsistent with the epistatic model (see text). (Adapted from Goldman D, Oroszi G, Ducci F. The genetics of addictions: uncovering the genes. Nat Rev Genet 2005;6(7):521-32.) 


\section{Heavy smokers vs non-smokers}

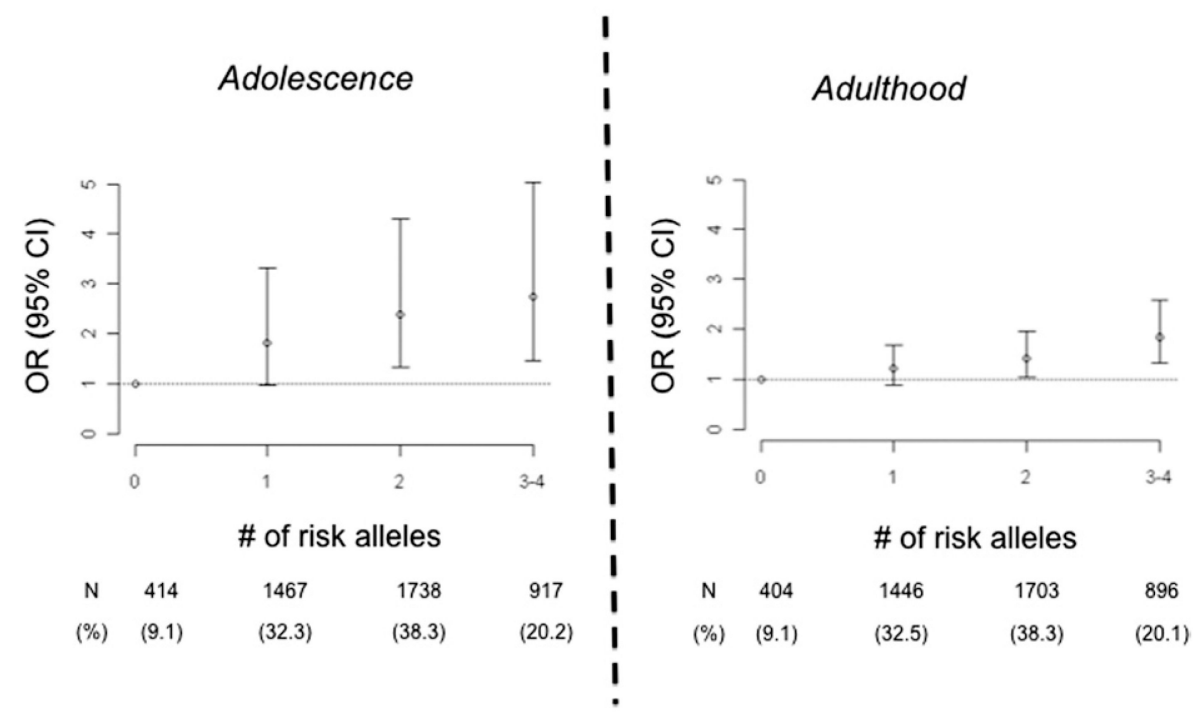

Fig. 5.

Additive effects of the TTC12-ANKK1-DRD2 and CHRNA5-CHRNA3-CHRNB4 gene clusters on smoking behavior in adolescence and adulthood. Risk of heavy smoking increases linearly with the number of risk alleles at the two loci. Odds ratios (OR) and $95 \%$ confidence intervals (CI). (Adapted from Ducci F, Kaakinen M, Pouta A, et al. TTC12ANKK1-DRD2 and CHRNA5-CHRNA3-CHRNB4 influence different pathways leading to smoking behavior from adolescence to mid-adulthood. Biol Psychiatry 2011;69(7):650 60.) 


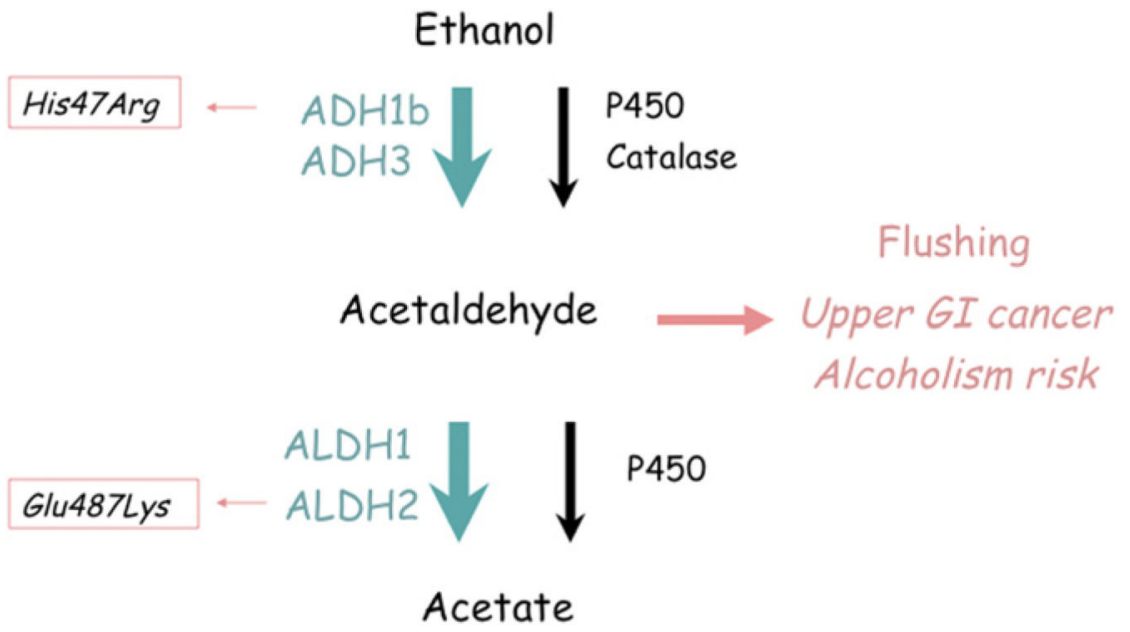

Fig. 6.

Functional polymorphisms in ethanol metabolism: $A D H 1 B$ His48Arg and $A L D H 2$

Glu487Lys. Higher activity of $A D H 1 B$, conferred by $A r g 48$, or lower activity of $A L D H 2$, conferred by $L y s 487$, leads to accumulation of acetaldehyde after alcohol consumption and the flushing reaction. 


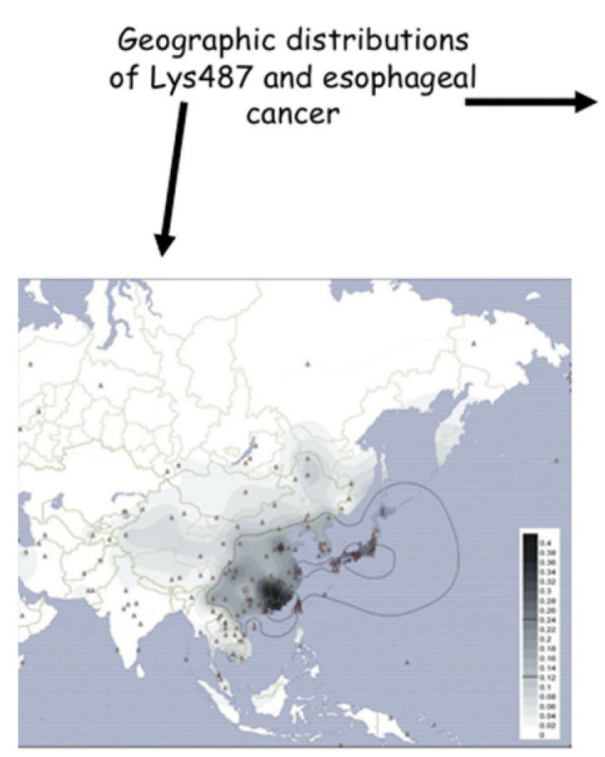

One genetic origin

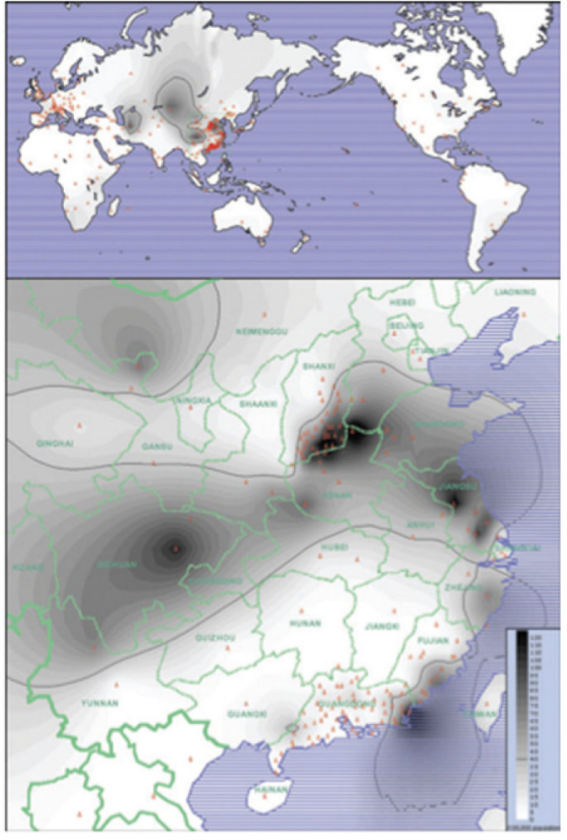

Fig. 7.

Geographic distributions of $A L D H 2$ Lys 487 and esophageal cancer. The Lys 487 allele is highly abundant in Southeast Asia but virtually absent in Europeans, Africans, and Amerindians. Southeast Asia is also an epidemiologic hotspot for esophageal cancer, consistent with genetic epidemiologic studies that have connected risk of esophageal cancer to moderate consumption of alcohol in carriers of the Lys 487 allele. Acetaldehyde is a carcinogen. ${ }^{58}$ (Adapted from Li H, Borinskaya S, Yoshimura K, et al. Refined geographic distribution of the oriental ALDH2*504Lys (nee 487Lys) variant. Ann Hum Genet 2009;73(Pt 3):335-45; with permission.) 

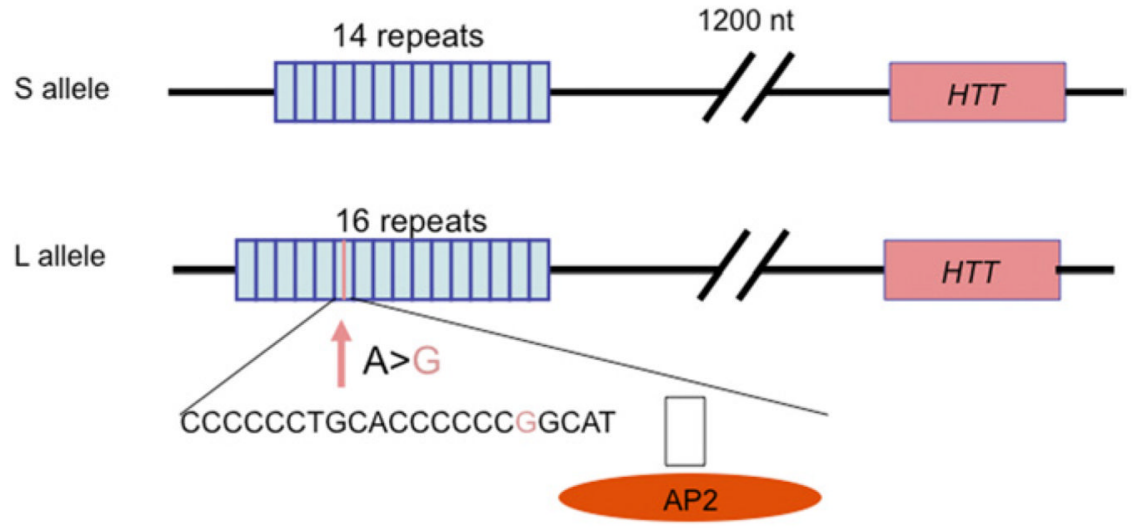

Fig. 8.

The serotonin-transporter-linked polymorphic region. The human serotonin transporter promoter has a common VNTR termed HTTLPR. The major alleles within this VNTR, namely $L$ (long) and $S$ (short), differ in number of copies of a 20-bpto23-bp imperfect repeat. The $L$ allele, which leads to increased transcription efficiency, has 16 copies of the repeat and the $S$ allele has 14 copies. Further, a relatively common, functional A > G SNP within the $L$ allele leads to an $L G$ allele functionally equivalent to the $S$ allele. (Data from Lesch KP, Bengel D, Heils A, et al. Association of anxiety-related traits with a polymorphism in the serotonin transporter gene regulatory region. Science 1996;274(5292):1527-31; and Hu XZ, Lipsky RH, Zhu G, et al. Serotonin transporter promoter gain-of-function genotypes are linked to obsessive compulsive disorder. Am J Hum Genet 2006;78(5):815-26.) 


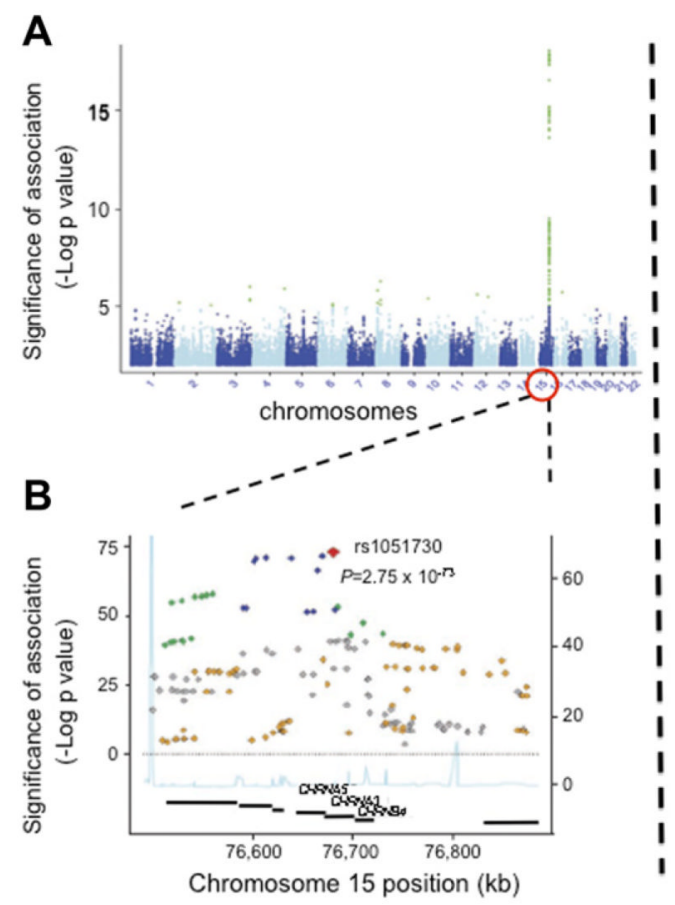

C

Effect of the protective allele

(Asp398) in CHRNA5 gene on

Number of cigarettes smoked/day

Fig. 9.

Association between smoking (number of cigarettes smoked per day, CPD) and genetic variation within the CHRNA5-CHRNA3-CHRNB4 gene-cluster on c15q25. (A) In the Manhattan plot, level of significance (-Log $P$ value) of association to SNPs covering 22 autosomes is shown. SNPs reaching genome-wide significance $\left(P<10^{-8}\right)$ are in green. $(B)$ The chromosome 15 region contains the CHRNA5-CHRNA3-CHRNB4 gene cluster. (C) The most significant SNP within this region is rs1051730, which correlates highly with Asp398Asn. (Data from Liu JZ, Tozzi F, Waterworth DM, et al. Meta-analysis and imputation refines the association of 15q25 with smoking quantity. Nat Genet 2010;42(5): 436-40; Hong LE, Gu H, Yang Y, et al. Association of nicotine addiction and nicotine's actions with separate cingulate cortex functional circuits. Arch Gen Psychiatry 2009;66(4): 431-41.) 
A

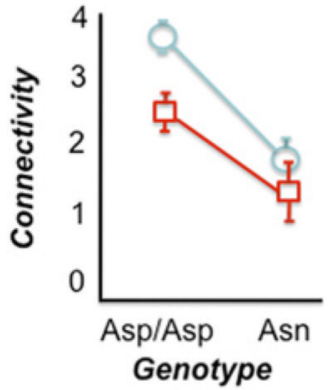

B

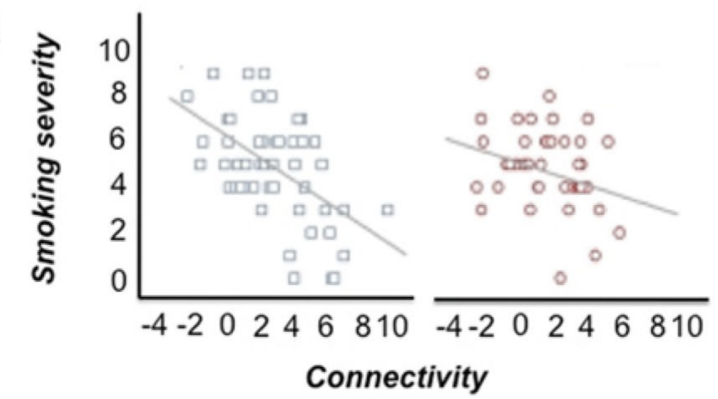

Psychiatric Patients

Healthy Subjects

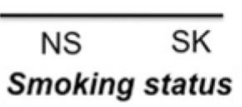

OPsychiatric smokers

Healthy smokers

Fig. 10.

Impact of psychiatric disease status, smoking behavior, and Asp398Asn influence on dorsal anterior cingulate-right ventral striatum functional connectivity. (A) Asn398 carriers as compared to Asp398/Asp398 homozygotes displayed reduced connectivity. Independently from genotype effect, reduced connectivity was also found in smokers (SK) vs nonsmokers (NS) and in psychiatric patients as compared to healthy participants. (B) Nicotine craving was negatively correlated with functional connectivity of dorsal anterior cingulate-ventral stria-tum in both smokers with and without psychiatric illnesses. (Adapted from Hong LE, Hodgkinson CA, Yang Y, et al. A genetically modulated, intrinsic cingulate circuit supports human nicotine addiction. Proc Natl Acad Sci U S A 2010;107(30):13509-14.) 
A: Rare allele: Brunner syndrome

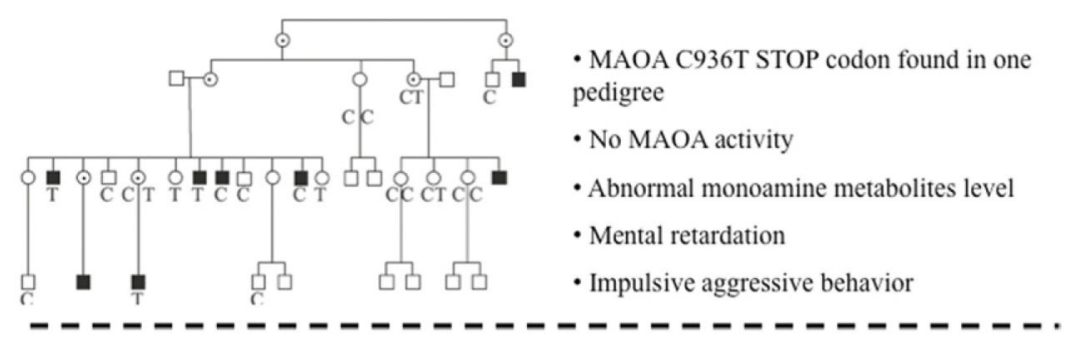

B: Common allele $(M A O A-L P R)$

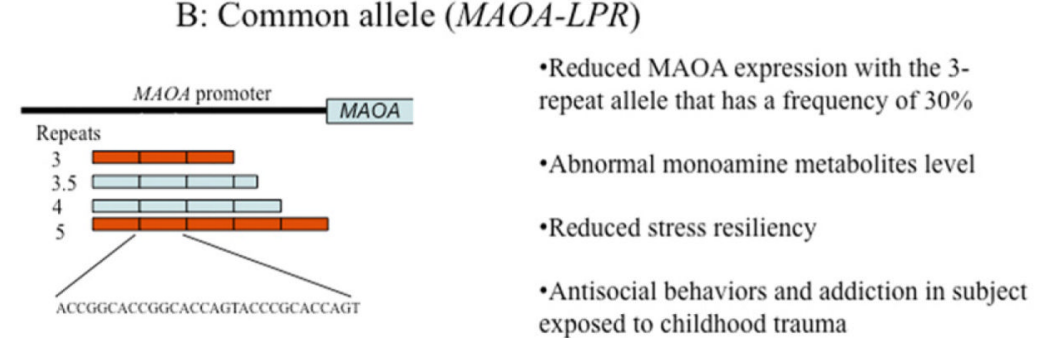

-Reduced MAOA expression with the 3-

Fig. 11.

Rare and common $M A O A$ variants. $(A)$ Dutch pedigree with eight males affected by Brunner syndrome, $\mathrm{X}$-linked behavioral dyscontrol caused by an $M A O A$ stop codon (C936T). (B) The MAOA-linked polymorphic region (MAOA-LPR) is a common 30-bp VNTR located approximately $1.2 \mathrm{~kb}$ upstream from the $M A O A$ start codon and within the transcriptional control region. The three-repeat allele is transcribed less efficiently, leading to lower $M A O A$ enzyme activity and behavioral consequences. ([A] Adapted from Brunner HG, Nelen M, Breakefield XO, et al. Abnormal behavior associated with a point mutation in the structural gene for monoamine oxidase A. Science 1993;262(5133):578-80.) 